\title{
„BILDHAUER IN STUTTGART, SONSTEN ABER AUS PRAG.“" ONDŘEJ FILIP QUITAINER JAKO ČLEN DRUŽINY PRAŽSKÝCH UMĚLCŮ V LUDWIGSBURGU V LETECH 1709-1714
}

\author{
MARTIN HOŘÁK \\ Ústav pro dějiny umění Filozofické fakulty Univerzity Karlovy \\ ma.horak@seznam.cz
}

\begin{abstract}
"Bildhauer in Stuttgart, sonsten aber aus Prag." Andreas Philipp Quitteiner as a member of the group of Prague artists in Ludwigsburg (1709 to 1714)

Prague sculptor Andreas Philipp Quitteiner (1679-1729) has not been thoroughly examined to date, including his works in the ducal residence of Ludwigsburg. The paper outlines the circumstances of the sculptor's departure to Ludwigsburg against the background of a recruiting trip undertaken by architect Johann Friedrich Nette (c. 1672-1714) to Prague in October 1708. The author poses the question of the extent to which Quitteiner's engagement reflected his position in contemporary Prague sculpture and divides Quitteiner's work in Ludwigsburg into two periods with a turning point occurring in September 1712 , when the artist lost his privileged position. In seven subchapters, the author focuses attention on the main sets of the sculptor's works: garden sculpture, allegorical sculptures of Caritas and Prudentia from the vestibule of the Ordensbau palace wing, decoration of the Fürstenbau main palace building, statues on the balustrade of the court of honour, decoration of the ceremonial staircase in the Riesenbau wing. By analysing the extant works, the author arrives at findings on the sculptor's sources of inspiration and models. The examined works are also analysed from an iconographic perspective and placed in the context of the ruling representation of Duke Eberhard Ludwig von Württemberg (1676-1733). Keywords: Ondřej Filip Quitainer / Andreas Philipp Quitteiner (1679-1729) - Ludwigsburg Palace - Johann Friedrich Nette (c. 1672-1714) - Prague baroque sculpture - baroque in Württemberg - European baroque sculpture
\end{abstract}

Württemberské vévodství procházelo na přelomu 17. a 18. století kritickým obdobím svých dějin. Nevelký protestantský stát na západní výspě říše se už vzhledem ke své poloze zaplétal do soupeření evropských mocností a jeho suverenitu dlouhodobě ohrožovala výbojná politika Ludvíka XIV. na rýnské hranici. Opakující se francouzské vpády vedly ke zpustošení jeho území a zbídačení obyvatelstva. V lednu 1693 nastoupil na vévodský stolec sotva sedmnáctiletý Eberhard Ludwig Württemberský (1676-1733), jehož čtyřicetiletá vláda přes některé své stinné stránky, jako např́iklad zadlužení státní pokladny nebo mezinárodní aféru vyvolanou vévodovým bigamickým vztahem $s$ Wilhelminou von Grävenitz, přinesla postupný návrat $\mathrm{k}$ mírovým časům. ${ }^{1}$ Okázalou demonstrací této

1 Základní životopisná data Eberharda Ludwiga Württemberského viz: Robert Uhland, Eberhard Ludwig, Herzog von Württemberg, in: Neue Deutsche Biographie (NDB), Band 4, Berlin 1959, s. 237-238. 
opětovné stabilizace a projevem vysokého sebevědomí lokálního monarchy, pyšného na své vojenské úspěchy pod velením prince Evžena Savojského, se měly stát nová vévodská rezidence a přilehlé město poblíž Stuttgartu. Oběma se brzy po jejich vzniku dostalo jména po jejich zakladateli: Ludwigsburg.

Zámecký areál vyrůstal od roku 1704 na místě bývalého honebního revíru Erlachhof nejprve jako lovecký zámeček a středisko rytířského řádu sv. Huberta, založeného Eberhardem Ludwigem v roce 1702. Posléze se Ludwigsburg stal novým reprezentativním sídlem vévodského dvora. Okolnosti vzniku této zámecké rezidence jsou dobře známy a v literatuře byly vícekrát zevrubně popsány. ${ }^{2}$ Uměleckohistorická literatura také již od počátku 20. století reflektuje, že na její stavbě a umělecké výzdobě se významně podíleli štukatéři, malíři a další umělci a řemeslníci pozvaní do Ludwigsburgu kolem roku 1708 z českých zemí, především pak z Prahy. ${ }^{3}$ Tato pražská umělecká mise je pozoruhodná jak počtem svých účastníků, tak rozsahem vytvořeného díla. Již v tomto ohledu nemá v kontextu českého barokního umění srovnání. ${ }^{4}$ Navzdory slibným badatelským počinům z posledních let jí však ani česká, ani německá uměnověda zatím nevěnovaly dostatečnou pozornost, a to zejména $\mathrm{z}$ hlediska mezinárodního srovnání. ${ }^{5} \mathrm{~K}$ nejméně prozkoumaným se řadí ludwigsburské práce jediného sochaře v rámci pražské umělecké družiny - Ondřeje Filipa Quitainera (1679-1729). ${ }^{6}$

(Dostupné také v digitální verzi: https://daten.digitale-sammlungen.de/0001/bsb00016320/images /index.html?seite=251; vyhledáno 5. 4. 2020.) Z novějších prací srov. zejména kolektivní monografii Staatliche Schlösser und Gärten Baden-Württemberg (Hrsg.), Schloss Ludwigsburg. Geschichte einer barocken Residenz. Silberburg, Tübingen 2004. Dále pak viz práci Corinny Höper a Andrease Henniga Das Glück Würtemberks, Zeichnungen und Druckgraphik europäischer Künstler des 18. Jahrhunderts, Stuttgart 2004.

2 Standardním dílem zůstává rozsáhlá syntéza Wernera Fleischhauera (Werner Fleischhauer, Barock im Herzogtum Württemberg, Stuttgart 1958.). Z novější literatury srov. zejména: Staatliche Schlösser und Gärten Baden-Württemberg (pozn. 1).

3 Na tuto skutečnost upozornil ve své disertaci z roku 1914 již Karl Weiß. Srov. Weiß, Schloß Ludwigsburg. Baugeschichtliche Abhandlung über die von Johann Friedrich Nette erbauten Teile. Ein Beitrag zur Kunstgeschichte des 18. Jahrhunderts, Stuttgart (Dissertation, Technische Hochschule Stuttgart), Stuttgart 1914. Do širšího povědomí vstoupila mj. díky Thieme-Beckerově lexikonu. Srov. [Werner Kudlich], heslo Quitteiner (Guittainer, Kwitagner, Quietainer), Andreas Philipp, in: Thieme-Becker Künstlerlexikon XXVII, Leipzig 1933, s. 529-530.

4 Na výzdobě zámku se z pražských umělců podíleli štukatéři Donato Giuseppe Frisoni a Tomasso Soldati, malíŕi Luca Antonio Colomba, Jan Jakub Steinfeld ze Steinfelsu, Johann Michael Bretschneider, Johann Schumann, Jan Pešina a sochař Ondřej Filip Quitainer. Z Brna přišel malír Emanuel Wohlhaupter, z Ostrova Vojtěch Kratochvíl (Adalbert Kratochwyl). Z umělců a řemeslníků působících před jejich příchodem do Ludwigsburgu v českých zemích W. Fleischhauer dále zmiňuje pozlacovače Zikmunda a Jeremiáše Kernerovy, Augusta Grandiho „a mnohé další, kteří s sebou privedli četné př́ibuzné ze svých rozvětvených uměleckých rodin, knimž patřili Retiové, Carloniové, Scottiové, Ferrettiové, Pedettiové, Bittiové a Corbelliniové. Srov. Werner Fleischhauer, Schlossmuseum Ludwigsburg, amtlicher Führer, Stuttgart 1958, s. 7-8.

5 Ve dnech 7. a 8. září 2009 uspořádal Ústav dějin umění Akademie věd ČR, v.v.i., česko-německé odborné setkání k připravovanému projektu Künstlerischer Austausch zwischen Prag und Ludwigsburg um 1700. Srov. Martin Mádl, Umělecká výměna mezi Prahou a Ludwigsburgem, Akademický bulletin Akademie věd České republiky, 2009, č.11, s. 24-25. Tomuto tématu se v poslední době opakovaně věnovala německá historička umění Ulrike Seegerová. Srov. její pražskou přednášku: Nette bei Alliprandi in Prag im Herbst 1708 und die Folgen für Schloss Ludwigsburg (Ústav dějin umění Akademie věd ČR, v.v.i., 26. 4. 2017).

6 Tato studie vychází z autorovy dizertační práce: Martin Hořák, Barokní sochařská dílna Ondřeje Filipa a Jana Antonína Quitainerových, Ústav pro dějiny umění FF UK, Praha 2019. 


\section{Okolnosti Quitainerova př́íchodu do Ludwigsburgu}

V březnu 1707 byl na doporučení vlivného dvorního maršálka a vrchního stavebního ředitele Georga Friedricha Forstnera jmenován architektem nově vznikajícího zámeckého komplexu Johann Friedrich Nette (kol. 1672-1714). Tento původně vojenský inženýr se narodil do rodiny stavitele varhan v Bernau u Berlína, vyrůstal v Sasku a studoval v Drážd’anech a ve Wittenbergu. ${ }^{7}$ Soudí se, že architektonické vzdělání získal v okruhu prusko-braniborského dvora $\mathrm{v}$ Berlíně. ${ }^{8}$ Jen $\mathrm{v}$ rovině spekulací přitom zůstávají úvahy o jeho prrípadném školení u některého $\mathrm{z}$ architektů působících v českých zemích. ${ }^{9}$ Důvod k nim zavdává především Netteho proslulá náborová cesta do Norimberka a do Prahy, na kterou se vydal počátkem ř́ina 1708 s úmyslem získat umělecké síly pro výzdobu právě dokončovaného hlavního traktu ludwigsburského zámku a přilehlých zahrad. ${ }^{10} \mathrm{~V}$ Praze se setkal s Giovannim Battistou Alliprandim, jehož tvorbu znal a obdivoval. ${ }^{11} \mathrm{~V}$ následujících letech se tak v Ludwigsburgu uplatnila řada umělců činných dříve na stavbách prováděných podle Alliprandiho návrhů. Vynikali mezi nimi zejména sešvagření štukatéŕi Donato Giuseppe Frisoni a Tommaso Soldati a malíri Luca Antonio Colomba a Jan Jakub Stevens ze Steinfelsu.

Náležel také Ondřej Filip Quitainer do okruhu Alliprandiho spolupracovníků? A nebyla důvodem jeho výběru právě tato „konexe“? Naše velmi kusé znalosti o počátcích uměleckého působení tohoto rodáka z Frýdlantu v Čechách, jenž přišel do Prahy na přelomu století, $v$ roce 1700 se přiženil do rodiny malostranského zlatníka a v roce 1707 je doložen jako autor sochařské výzdoby Březnické brány na Svaté Hoře u Př́brami, bohužel na tyto otázky nedávají odpověd. Dávné tvrzení Jana Quirina Jahna, ${ }^{12}$ že Quitainer měl podíl na výzdobě Alliprandiho malostranského trojičního sloupu, zpochybnil již na počátku 20. století Jan Herain. ${ }^{13} \mathrm{Na}$ stavbách Alliprandiho pražských paláců není Qui-

7 Srov nejnověji Klaus Merten, Baugeschichte von Schloss Ludwigsburg bis 1721, in: Staatliche Schlösser und Gärten Baden-Württemberg (pozn. 1), s. 12. Dvornímu maršálkovi Forstnerovi architekta doporučil jeho švagr, generál Sternenfels, v jehož oddílech Nette sloužil.

8 Ibidem.

9 Ulrike Seeger, Vienna, Prague, Paris and Augsburg: The Provisioning of Interior Decoration in the Ludwigsburg Residence, in: Spephan Hoppe - Krista Breitling - Stefan De Jonge (eds.), The Interior as an Embodiment of Power, Heidelberg 2018, s. 194.

10 Fleischhauer, Barock im Herzogtum (pozn. 2), s. 148. Autor klade tuto cestu až na začátek roku 1709. Novější literatura uvádí ŕíjen 1708. Srov. Merten (pozn. 7), s. 16. V biografické stati Piuse Bieriho na portálu Süddeutscher Barock jsou bez odkazu uvedeny dvě Netteho cesty do Prahy. Srov. http://www .sueddeutscher-barock.ch/In-Meister/h-r/Nette_Johann_Friedrich.html, vyhledáno 19. 4. 2020.

11 Okolnosti Netteho cesty na podzim 1708 popsala ve své pražské př̌ednášce z 26. 4. 2017 Ulrike Seegerová (viz pozn. 5) včetně odkazů na archivní prameny württemberské provenience, dokládající Netteho setkání s Alliprandim.

12 V životopisném medailonu F. M. Brokoffa v Pelclových Abbildungen označil Jahn Quitainera za Brokoffova učitele a za společné dílo obou sochařủ malostranský trojiční sloup a mariánský sloup na Hradčanském náměstí. Srov. František Martin Pelzel, Abbildungen böhmischer und mährischer Gelehrten und Künstler II., Prag 1775, s. 171. Připsání malostranského sloupu Quitainerovi se objevuje i v Jahnových rukopisných poznámkách k topografii Malé Strany. Srov. Lubomír Slavíček, Jan Quirin Jahn, topograf uměleckých památek Prahy, in: Pražský sborník historický XLII, 2014, s. 329.

13 Podle Herainem publikovaného archivního nálezu přijali v ř́ijnu 1713 zálohu na sochařskou výzdobu sloupu Ferdinand Geiger a Jan Oldřich Mayer. Srov. Jan Herain, Stará Praha, sto akvarelư Václava Jansy I, Praha 1902. Později vyšlo najevo, že Quitainer od roku 1709 působil v Ludwigsburgu, a vznikla tak pochybnost, zda v době vzniku sloupu (1713-1715) byl v Praze. Jak však ukazuji níže, v letech 1712-1714 pobýval sochař v Ludwigsburgu s přestávkami. V ř́ijnu 1713 křtil v Praze dceru a jeho 
tainer doložen a jejich sochařskou výzdobu s ním nelze spojit ani na základě formálně stylové analýzy. ${ }^{14}$

$\mathrm{Na}$ druhou stranu dlužno připomenout, že Quitainer byl spolu s Alliprandim součástí téhož sociálního mikrosvěta pražské Malé Strany, ${ }^{15} \mathrm{v}$ němž slavnému architektovi př́slušelo postavení neformální autority a hlavy italské umělecké komunity. ${ }^{16}$ Také tyto osobní vztahy mohly Quitainerův výběr pozitivně ovlivnit - stěží však jsou jeho jediným vysvětlením. Nepřímo to dokládá epizoda ze srpna 1708, kdy se Nette dostal do sporu s württemberským dvorním sochařem Sebastianem Zimmermannem. Vytkl mu nízkou kvalitu dvou dodaných soch a odmítl s ním dále spolupracovat na výzdobě zámeckých zahrad. ${ }^{17} \mathrm{~V}$ době své cesty do Prahy tak architekt postrádal sochaře, jemuž by mohl svěrit úkoly vyplývající $\mathrm{z}$ aktuální stavební etapy. Je málo pravděpodobné, že by si za těchto okolností náhradou za etablovaného Zimmermanna přivedl začínajícího sochaře, a to pouze na základě osobní př́mluvy.

Quitainerovým prvním úkolem byla práce na souboru zahradní plastiky. Očekávalo se, že bude schopen pracovat s grafickými předlohami a ztvárňovat náměty z klasické mytologie v takové kvalitě, aby sochy v zahradních parterech obstály i při pohledu na blízkou vzdálenost a z různých úhlů. Rozsah zakázky a tlak na rychlost jejího provedení zároveň předpokládaly sochaře, který byl schopen umělecky i organizačně zvládnout chod početné dílny. Jestliže Oldřich J. Blažíček ve své syntéze českého barokního sochařství z konce padesátých let 20. století soudil, že pražský sochař „začal jistě v drobnějších úkolech po boku starších rutinérů a podle architektova rozvrhu“, ${ }^{18}$ na základě dnešního

poslední vyúčtování v Ludwigsburgu pochází z poloviny května 1714. Z ryze časového hlediska proto nelze jeho participaci na monumentu vyloučit.

14 V rámci Alliprandiho pražských palácủ je neobjasněno především autorství sochařské výzdoby Přehořovského (Lobkovického) paláce na Malé Straně. Dvě sousoší Únosů na piliřích čestného dvora se Quitainerovu sochařskému projevu vymykají svou kompoziční složitostí a monumentální koncepcí. Dosavadní literatura je klade do souvislosti s vídeňskou tvorbou Lorenza Mattielliho. Srov. Emanuel Poche - Pavel Preiss, Pražské paláce, Praha 1977, s. 60 a obr. 44. Čtyři mohutné alegorické postavy z atiky, jež jsou nyní umístěny v horní části zahrady německého velvyslanectví, zachycuje již rytina B. Wernera ze 40 . let 18 . století, a musely tak být vytvořeny ještě před pozdně barokní úpravou paláce. Hrubé zpracování a hypertrofované tvarosloví těchto architektonických plastik zásadním způsobem omezují možnosti jejich stylové analýzy. Archivní materiály ke stavbě paláce se vzhledem ke kridě uvalené na jeho první majitele zachovaly torzálně a Quitainerovo jméno v nich nefiguruje. Srov. Dobroslav Líbal (ed.), Stavebně historický prưzkum, Palác Přehořovských z Kvasejovic. Malá Strana č.p. 347/ III, Praha 1968. Jiř́ Kaše, Projekt restaurátorské akce. Sochařská výzdoba palácové atiky, č.p. 347/III Vlašská 19, Lobkovický (Přehořovský) palác, Praha 1985.

15 Oba bydleli v Ostruhové (Nerudově) ulici, křtili své děti v nedalekém kostele sv. Tomáše a setkávali se s podobným okruhem přátel, do něhož patřili i zmínění štukatéři Frisoni a Soldati nebo sochař Jan Oldřich Mayer, který byl Quitainerovým švagrem. Už v lednu 1700 se Alliprandi se Soldatim účastnili křtu Mayerova syna Jana Martina. Srov. Antonín Podlaha: Materiálie ke slovníku umělců a uměleckých řemesel v Čechách, Památky archeologické XXXII, 1920-1921, s. 274. Blíže ke Quitainerovu sociálnímu zakotvení v prostředí Malé Strany: Hořák (pozn. 6), s. 33-34.

16 Martin Krummholz, Giovanni Battista Alliprandi, in: Petr Macek - Richard Biegel - Jakub Bachtík (eds.), Barokní architektura v Čechách, Praha 2015, s. 181-187, s. 236-248.

17 Hauptstaatsarchiv Stuttgart, Bü 2264, Dopis dvorního sochaře Sebastiana Zimmermanna vévodovi Eberhardu Ludwigovi z 5. srpna 1708. Excerpta archivních materiálů k působení O. F. Quitainera v Ludwigsburgu mi laskavě poskytla prof. Ulrike Seegerová. Na většinu těchto pramenů upozornil ve své syntéze z roku 1958 již Werner Fleischhauer. V tomto příspěvku odkazuji, pokud možno, na primární archivní zdroje.

18 Oldřich J. Blažíček, Sochařství baroku v Čechách, Praha 1958, s. 118. 
stavu poznání se jeví, že třicetiletý Quitainer odcházel z Prahy mnohem lépe odborně vybaven. Tento předpoklad potvrzují i jeho první sochařské realizace v Ludwigsburgu, byt’ nadále zůstává neobjasněno, kdy a kde si své zkušenosti a dovednosti osvojil. ${ }^{19}$

\section{Výzdoba ludwigsburských zámeckých zahrad}

Pod Netteho vedením byly v Ludwigsburgu zakládány také rozlehlé zámecké zahrady. Kromě severní terasovité zahrady, jejíž dispozice zůstala v zásadě zachována dodnes, se jednalo o později zrušenou velkolepou zahradu před jižním průčelím hlavního zámeckého traktu Fürstenbau (Altes Corps de logis). Její ideální podobu známe ze souboru rytin podle Netteho vedut, vydaného tiskem v Augsburgu pod názvem Veues et parties principales de Louis-Bourg. ${ }^{20}$

Přísně osově organizovaná zahrada francouzského typu sestávala ze dvou parterů propojených centrální komunikací, navázanou na zahradní průčelí Fürstenbau. Do prvního parteru s oválným bazénem uprostřed se scházelo po dvou schodištích z nízké terasy před zámeckou budovou. Plocha parteru se členila na čtyři pole s okrasnými dřevinami a její jižní stranu zakončovala nízká balustráda, která je na grafickém listu osazena přibližně dvaceti sochami či ozdobnými kamennými vázami. Uprostřed vstupní terasy měla stát jezdecká socha Eberharda Ludwiga jako point de vue celého zahradního areálu.

Plocha druhého, rozlehlejšího parteru je na vedutě rozdělena radiálně vedenými cestami do osmi úseků s brodériemi. Na obou koncích prŕíné osy byl plánován polygonální pavilon a v rozích zahrady se počítalo se čtyřmi bazény nepravidelného půdorysu. Uprostřed parteru měl vzniknout velký oválný bazén s obeliskem uprostřed. Na ohradní zdi lze opět spatřit bohatou sochařskou výzdobu.

Výsledná podoba této okrasné a kratochvilné zahrady doznala oproti představenému návrhu nepochybně změn. V letech 1709 až 1710 byly například před vstupem do zámku postaveny dvě ruiny antických kolonád, jež na vedutě nejsou zachyceny. Svého vzniku se naopak nedočkala vévodova jezdecká socha. ${ }^{21}$ Podle archivních zpráv o průběhu stavebních prací v letech 1709 až 1712 však tyto úpravy neproběhly na úkor velkorysého rozvrhu zahrady, jež byla $\mathrm{v}$ zásadě založena podle Netteho plánů. ${ }^{22} \mathrm{Z}$ hlediska našeho tématu je však otázkou, jak rychle postupovaly práce na sochařské výzdobě a nakolik se do nich ještě stihl zapojit Quitainer, který v záŕí 1712 - jak ještě uvidíme - ztratil v Ludwigsburgu postavení vedoucího sochaře. Podle svědectví uměnímilovného cestovatele Johanna

19 Do nového světla se tak dostává názor J. B. Dlabače, že Quitainer si v Čechách získal reputaci již brzy po začátku 18. století, přičemž jeho úspěšná kariéra se údajně odvíjela od sochařské výzdoby zámecké zahrady v Dolní Lukavici. Gottfried Johann Dlabacž, Böhmische Künstler, in: Hesperus. Ein Nationalblatt für gebildete Leser 82, Dezember 1813, col. 650-651. Idem, Allgemeines historisches Künstlerlexikon für Böhmen und zum Theil auch für Mähren und Schlesien, Band I.-III, Prag 1815, col. 517-518. Podle novějších výzkumů vznikla tato zahrada pravděpodobně až ve druhé stavební etapě po roce 1724 . Z výzdoby zahrady se dochovalo jen několik zlomků ozdobných kamenných váz. Nejnověji srov. Hořák (pozn. 6), s. 203-204. Zde i odkazy na starší literaturu.

20 Srov. Merten (pozn. 7), s. 10 a 12.

21 Ke stavebnímu vývoji zahrady srov. Fleischhauer, Barock im Herzogtum (pozn. 2), s 145-146.

22 Srov. nejnověji Höper - Henning (pozn. 1), s. 9. Zde i odkazy na starší literaturu. 
Friedricha Uffenbacha z podzimu 1712 byla zahrada rozlehlá, její výzdoba však zatím čítala jen houf putti a deset až šestnáct soch kolem centrální vodní plochy. ${ }^{23}$

S Quitainerem se v Ludwigsburgu na základě písemných pramenů poprvé setkáváme v závěru roku 1709. Dne 17. prosince obdržel první splátku honoráře za plastiky Dia$n y$, Meleagra a třetí nespecifikovanou sochu pro zámecké zahrady. ${ }^{24}$ Tehdy již musely být vylámány pískovcové bloky a připraveny k opracování, což vede k závěru, že sochař na místě již nějakou dobu pobýval. V Praze je naposledy doložen 18. srpna 1709, kdy křtil syna Jana Antonína, budoucího sochaře. Za povšimnutí stojí, že zmíněné prosincové datum spadá do doby mimo stavební sezónu, a lze tak předpokládat, že Quitainer, označený v dokladu jako „Bildhauer in Stuttgart, sonsten aber aus Prag“, žil v té době ve Württembersku trvale. ${ }^{25}$ Druhá splátka mu byla vyplacena 21 . února 1710 a doplatek o dva měsíce později, 19. dubna 1710, když již byly sochy nejspíše dokončeny. Sochař v té době pracoval na figuře Bakcha. ${ }^{26}$

Z tohoto prvního souboru doložených prací se zachovala především nadživotní socha Meleagra ze zámeckého lapidária. ${ }^{27}$ Mladého přemožitele kalydónského kance představuje $\mathrm{v}$ mírném kontrapostu a $\mathrm{v}$ uvolněném postoji s dlaní pravé ruky ležérně položenou na kančí hlavě, posazené na pahýlu stromu za lovcovými zády. Dílo dokládá, že sochařův obzor byl kolem roku 1710 širší a bohatší, než by se mohlo zdát na základě jeho dosud známé domácí tvorby. ${ }^{28} \mathrm{~V}$ transformované podobě, se zrcadlově obrácenou polohou volné a nosné nohy, cituje socha slavného Meleagra Belvedérského z vatikánských sbírek, ${ }^{29}$ současně ale udivuje autorovou důvěrnou znalostí vrcholně barokní recepce antické tradice. V porovnání s uvedenou předlohou vybavil Quitainer svého hrdinu dynamičtější pohybovou kompozicí, nesenou zhoupnutím v bocích a návaznou šroubovicí tělesné osy. Jeho Meleagros je nadto robustnější. Mohutné svalstvo je anatomicky věrně podáno a zároveň měkce modelováno v duchu tradice odkazující až k římskému malířství a sochařství první poloviny 17. století. Pečlivé sochařské zpracování všech pohledových rovin i malebné podání detailů, jako je elegantní luk s reliéfní výzdobou nebo svěže realistická kančí hlava, naznačují, že se mohlo jednat o ukázkový kus, jímž se chtěl pražský sochař v novém působišti co nejlépe uvést. Nehledě na některé

23 „Der Garten ist sehr räumlich angelegt, aber mit nichts bis dato ausgeziert außer einige gacons [!] und 10 bis 16 Statuen in der mite davon springet ein Strahl wasser aus einem Baßin aber nicht hoch dück von wasser". Srov. Merten (pozn. 7), s. 23.

${ }^{24}$ Hauptstaatsarchiv Stuttgart, Rentkammer-Rechnungsbuch, Bü 970, 1709-10, fol. 156, Potvrzení o platbách O. F. Quitainerovi za sochy Diany, Meleagera a za třetí nejmenovanou sochu (1709-1710). Za tyto tři sochy mu bylo zaplaceno celkem $300 \mathrm{zl}$.

25 „Andreas Philipp Quitteiner, Bildhauer in Stuttgart, sonsten aber aus Prag“. Ibidem.

26 Ibidem.

27 Nejnověji k této soše: Hořák (pozn. 6), s. 117-119. Zde i odkazy na starší literaturu. Údaje o umístění sochařských děl, pojednaných v této studii, odpovídají situaci v době místní obhlídky v dubnu 2017. Novodobá kopie sochy Meleagra je umístěna na stř̌ešní balustrádě jižního, zahradního průčelí zámeckého traktu Neues Corps de logis.

28 Z doby před jeho odchodem do Ludwigsburgu je znám jediný soubor jeho děl: výzdoba Březnické brány na Svaté Hoře u Př́brami z roku 1707. Tyto práce - sv. Jáchym a sv Anna po boku kopie Panny Marie Svatohorské a šestice byst na atice - jsou hluboce zakotveny v tradici pražského sochařství a řezbářství druhé poloviny 17. století. Podrobněji srov. Hořák (pozn. 6), s. 113-115.

29 Za upozornění na tuto inspirační vazbu děkuji Mgr. Kateřině Adamcové, Ph.D. Dále srov. prezentaci uvedené antické sochy na internetových stránkách Pio Clementino Museum: http://www.museivaticani.va/content/museivaticani/en/collezioni/musei/museo-pio-clementino/sala-degli-animali /meleagro.html, vyhledáno 15. 4. 2020. 
proporční nedokonalosti, jako poněkud krátké nohy a masivní hýždě, podal Quitainer pozoruhodný výkon a vytvořil jeden z nejlepších mužských aktů antikizující koncepce, jaký vznikl rukou pražského sochaře před vrcholnými díly Ferdinanda Maxmiliána Brokoffa. ${ }^{30}$

Do skupiny Quitainerových zahradních plastik se dále řadí socha Bakcha uložená bez uvedení autora $\mathrm{v}$ depozitáři lapidária. ${ }^{31}$ Představuje antického boha jako mladého muže plné postavy a kulatých tváŕí, jenž stojí opřen zády o pahýl stromu a v rukou drží velký hrozen vína. Na ostatní Quitainerovy práce v Ludwigsburgu se socha odvolává charakteristickou kontrapozicí hlavy a horní poloviny těla s náznakem rotačního pohybu kolem tělesné osy. Sochařovu projevu odpovídají i šikmé paralelní záhyby drapérie na boku postavy, plasticky výrazné podání svalstva a typika obličeje s hluboko zasazenýma mandlovitýma očima.

K Bakchovi se námětově váží postavy dvou archivně nedoložených bakchantek, jejichž originály jsou druhotně umístěny v nikách saly terreny v průchodu Neues Corps de logis, zatímco kopie zdobí střešní balustrádu jižního průčelí téhož zámeckého traktu. ${ }^{32}$ Vzhledem k naznačené ikonografické vazbě mohly být sochy součástí Bakchova průvodu a tvořit spolu s ním jednu sochařskou skupinu.

Bakchantka se džbánem na víno a satyrkem ztělesňuje dívku ve splývavých šatech s vysoko nasazeným pasem a odhalenými ňadry. Socha vykračuje levou nohou a klade ji na nízký pařez. Ve výši svého pravého prsu drží oběma rukama džbán s dlouhým hrdlem. Hlavu sklání k levému rameni a pohledem klouže ke svým nohám, kde cupitá rozjařený satyrek s kalichem v levé ruce. Protějšková Bakchantka s holí ovinutou břečtanem (thyrsem) klade pravou nohu na spodní stupínek nízkého dvouúrovňového podstavce, zatímco její levá noha ještě spočívá na vyšším stupni. Tento sestupný pohyb motivuje vyklenutí boků a dává tak vyniknout smyslně oblým tvarům ženského těla.

Werner Fleischhauer zhodnotil Quitainerovy bakchantky jako těžkopádné a neohrabané („plump“). ${ }^{33}$ Obě sochy jistě vznikly za součinnosti dílny. Dokládají to detaily rukou, vlasů a obličejů, postrádající na rozdíl od sochařových vrcholných kreací tendenci $\mathrm{k}$ individuaci typových vzorců. Také splývavá antikizující drapérie je nevýrazná a její členění dlouhými paralelními záhyby působí mechanicky. Přes tyto nedokonalosti a celkovou neobratnost při ztvárnění ženské postavy jsou obě práce zajímavým dokladem Quitainerovy snahy vyrovnat se s žánrovými nároky zahradní plastiky. Z vývojového hlediska stojí za pozornost, že jejich senzualismus a erotismus předznamenává raně rokokovou tvorbu sochařova syna Jana Antonína (1709-1765), jejíž dekorativní aspekty dosud nebyly s možnými inspiračními vlivy staršího Quitainera spojovány.

30 Antikizující pojetí charakterizuje také téměř současného Krista Salvátora z mosteckého sousoší Krista s Kosmou a Damiánem, dílo J. O. Mayera z roku 1709. Ve srovnání s Quitainerovou prací se jedná po postavu křehčí tělesné stavby a odlišného - více „grafického“ - způsobu modelace.

31 Dílo jsem Quitainerovi připsal ve své dizertační práci. Srov. Hořák (pozn. 6), s. 171-172. Mohlo by být totožné se sochou uvedenou v prvním archivním dokladu vztahujícím se ke Quitainerovu působení v Ludwigsburgu. Srov. Hauptstaatsarchiv Stuttgart, Rentkammer-Rechnungsbuch, Bü 970, 1709-10, fol. 156 (pozn. 25).

32 Tato díla zahrnul mezi Quitainerovy práce již Fleischhauer. Srov. Fleischhauer, Barock im Herzogtum (pozn. 2), s. 149.

33 Ibidem. 
V zámeckém lapidáriu je dále vystavena a našemu sochaři právem připsána archivně nedoložená pískovcová socha Kyklopa Polyféma. ${ }^{34}$ Řadí se k jeho nejdynamičtějǐím kompozicím a zachycuje mohutnou postavu v rotačním pohybu s napřahující se levou rukou, zapřenou pravou nohou a hlavou natočenou ve směru očekávaného úderu. $V$ chybějící dlani své levé ruky Kyklop nejspíše držel atribut, jímž byl - jak navrhla Petra Nevímová kámen. Socha se totiž inspirovala jedním ze dvou vyobrazení Polyféma na caracciovských freskách v ř́mském Palazzo Farnese (1597-1607), ${ }^{35}$ jehož námět vychází z třinácté knihy Ovidiových Proměn, v níž se praví, že Polyfémos v návalu zuřivosti kvůli neopětované lásce k Nereovně Galatei vyrval ze země kus skály a vrhl jej na prchající mileneckou dvojici Galateu a Ákida. Druhého ze jmenovaných přitom zabil. ${ }^{36}$

Jak upozornil již Rudolf Wittkover, maliřské dílo Annibala Carracciho a zvláště jeho fresky na námět lásky antických bohů z uvedeného římského paláce sehrály zásadní roli v recepci a transformaci antického tělesného kánonu a při formování nového pojetí exprese v římském sochařství první poloviny 17 . století. ${ }^{37}$ Polyfémův vražedný pohyb, ztuhlý ve zlomovém okamžiku probíhajícího dramatu, označil Wittkower za předobraz Berniniho Davida. ${ }^{38}$ Quitainer však přejímá tento dynamizující prvek v transformované podobě. Návaznost na Carracciho či Berniniho je nepřímá, nebot jeho Polyfémos má jen mírně rozkročené nohy v bezmála tanečním úkroku, a přetočení horní poloviny těla tak nedokáže dostatečně věrohodně navodit dojem razantního rozmáchnutí. Do hry patrně vstoupily i jiné předlohy. V rámci soudobého evropského sochařství přichází v úvahu zejména socha Neptuna ze střechy berlínské vily Kamecke. ${ }^{39} \mathrm{~S}$ tímto pozdním dílem Andrease Schlütera z let 1711-1712 mohl Quitainera seznámit jeho přímý nadřízený v Ludwigsburgu, architekt Johann Friedrich Nette. Ten je se schlüterovským okruhem spojován jednak na základě svého předpokládaného uměleckého školení v Braniborsku a dále v souvislosti s vlivy architektury berlínského zámku na ludwigsburskou rezidenci. ${ }^{40}$ Berlínský Neptun se Quitainerovu Polyfémovi podobá nejen zmíněným úkrokem, ale také pohyby paží, vzdutou drapérií na bocích a hladkou modelací svalstva, zdůrazňující táhlé linie nohou. Osobitý př́nos pražského sochaře se projevuje zejména drsným pseudorealismem obličeje se stylizovanými vlasy a vousy, jejichž pečlivě vypracované zákruty mohou odkazovat na Ovidiovou zmínku, že Po-

34 Podrobněji srov. Hořák (pozn. 6), s. 175-176.

$35 \mathrm{Na}$ tuto souvislost upozornila Petra Nevímová v oponentském posudku k autorově dizertační práci. Srov. repozitář závěrečných prací Univerzity Karlovy (https://is.cuni.cz/webapps/zzp/detail /147095/?lang=cs, vyhledáno 9. 4. 2020).

36 Publius Ovidius Naso, Proměny, Praha 1969, s. 406.

37 Rudolf Wittkower, Art and Architecture in Italy: 1600-1750, 3rd. revised edition, Harmondsworth, Baltimore, Ringwood 1973, s. 35-36.

38 Rudolf Wittkower, Gian Lorenzo Bernini, 3rd. edition, Ithaca, New York 1981, s. 5-6.

39 Bode-Museum Berlin Skulpturensammlung Inv. Nr. 8656, vystaveno v Kameckehalle (srov. virtuální prohlídku muzea http://bode360.smb.museum/, vyhledáno 11. 4. 2020). K vile Kamecke a její sochařské výzdobě srov. nejnověji Julia Kloss-Weber, Die Villa Kameke, in: Hans-Ulrich Kessler (ed.), Andreas Schlüter und das barocke Berlin, Berlin 2014, s. 416-435. Autorka srovnává sochu Neptuna s Berniniho Tritonem z rrímské Maurovy fontány (Fontana del Moro) a demonstruje tak Schlüterův odklon od vrcholně barokní monumentality a dramatičnosti. Anticipace pozdně barokního výrazového zjemnění v závěru Schlüterovy tvorby se podle autorky projevuje mimo jiné právě Neptunovým elegantním postojem.

40 Srov. Merten (pozn. 7), s. 23. 
lyfémos pod dojmem svého citu ke Galatei začal pečovat o dosud zanedbávaný porost své hlavy. ${ }^{41}$

Řada barokních soch či jejich zlomků z různých časových období je uložena ve skladišti lapidária a dosud čeká na odborné zpracování. ${ }^{42}$ Kromě výše uvedeného Bakcha, k jehož vzniku se pravděpodobně váže zmíněný archivní záznam z roku 1710, lze pražskému sochaři stylovou analýzou připsat torzo Herkula s Kerberem. ${ }^{43}$ Soše Herkula chybí obě předloktí a postava má téměř setřeny rysy tváře. Přes úbytek výtvarných kvalit v důsledku mechanických poškození je ale Quitainerovo autorství zřejmé. Odkazuje k němu symbióza realistického a malebného pojetí vypracovaného svalstva, jíž se Quitainerův rukopis lišil od alegorizující manýry štíhlých a hladkých soch jeho současníků a konkurentů v Ludwigsburgu - sochařo Sebastiana Zimmermanna a Giorgia Ferrettiho. ${ }^{44}$

Zlomkovitě zachovaný fond zahradní plastiky a nedostatek písemných či obrazových pramenů ztěžují určení původní ikonografické koncepce sochařské výzdoby obou parterů libosadu. ${ }^{45}$ Quitainerovy první doložené práce z roku 1710 (dochovaný Meleagros a nedochovaná Diana) se vztahují k lovu a symbolizují prvotní účel zámecké rezidence, zamýšlené nejprve jako lovecký zámek a centrum vévodou založeného řádu sv. Huberta. Bukolickou idylu venkovského sídla v panenské krajině měl navozovat Bakchus a Bakchantky. Herkulovské téma, opakující se v Ludwigsburgu v četných variacích, je součástí panovnické reprezentace vévody Eberharda Ludwiga jako vzorného panovníka a neohroženého křestanského rytíře. Socha žárlivého Polyféma navozuje téma milostného vzplanutí a síly lásky, k němuž se mohla vztahovat také socha Venuše s amorkem, dochovaná v kopii na stř̌ešní balustrádě nové zámecké budovy (Neues Corps de logis), ${ }^{46}$ stejně tak jako houf putti, zmíněný v dopise Johanna Friedricha Uffenbacha. ${ }^{47}$

41 „Již své postavy dbáš, již hledíš, aby ses líbil, kopáčem, Polyféme, si češeš trčící vlasy, již se ti odtínat chce též srpem ježaté vousy". Publius Ovidius Naso (pozn. 36), s. 402 (přel. Ferdinand Stiebitz).

42 Děkuji pracovníkům správy Rezidenčního zámku Ludwigsburg (Residenzschloss Ludwigsburg) za možnost navštívit veřejnosti nepř́ístupné zázemí lapidária a pořídit fotodokumentaci vybraných sochařských děl.

43 Toto nepublikované dílo připisuji Quitainerovi ve své dizertační práci. Srov. Hořák (pozn. 6), s. 174175.

44 Podrobněji k Zimmermanovi a Ferrettimu srov. Fleischhauer, Barock im Herzogtum (pozn. 2), s. 148150. Z novějš́ literatury: Daniel Schulz, Mars, Venus, Bacchus \& Co.: Die barocken Groß-Skulpturen des Ludwigsburger Schlosses, in: Ludwigsburger Geschichtsblätter 64/2010, s. 33-36, 39-42. Rozdíl mezi Quitainerem a těmito sochaři spočíval především v odlišném poměru alegorické a realistické složky. Quitainerova realistická východiska se míjela s neosobní stylizací a alegorizací v podání těchto sochařù. Ve Ferretiho prŕpadě byl tento př́ístup nadto spojen se zručností při vytváření pohybově živých skupin (srov. jeho práce Únos Filyry a Únos Proserpiny z r. 1716; dnes na altánu Neues Corps de logis), které naopak nebyly Quitainerovou doménou.

45 V okolí zámku se kromě děl pojednaných v této studii nachází několik novodobých kopií barokních soch. Celkem čtyři jsem zaznamenal při místní obhlídce v dubnu 2017: Ledu s labutí v jihovýchodní části zahrady před Neues Corps de logis (tzv. Mathildengarten), neznámou antickou bohyni a gladiátora ve výklencích romantické ruiny pseudoantického akvaduktu a hudebníka se strunným nástrojem v rukou, s tornou přes rameno a čapkou na hlavě - snad Apollóna - ve výklenku romantické hradní zříceniny. Quitainerovým kompozičním a modelačním řešením se nejvíce podobají sochy neznámé bohyně a Apollóna. Kvalita všech těchto kopií je ale natolik nízká, že neumožňuje určení autorství na základě stylové analýzy. Za upozornění na tato díla a jejich umístění děkuji panu Danielu Schulzovi.

46 Tuto sochu připisují Quitainerovi bez uvedení dalších podrobností akta stavebního úřadu z roku 1905. Srov. Schulz (pozn. 43), s. 33. Ve své dizertační práci se s touto atribucí ztotožňuji. Srovnání dalších kopií na balustrádě s Quitainerovými originály nicméně ukazuje na přibližnost těchto kopií. Srov. Hořák (pozn. 6), s. 176-177.

${ }^{47}$ Merten (pozn. 7), s. 23. 


\section{Sochařské práce v zámeckém křídle Fürstenbau}

Počínaje rokem 1710 se Quitainer v Ludwigsburgu uplatnil i jako řezbář. Většina jeho prací ve dřevě - čtyři stolky, hrací stůl a rámy zrcadel či obrazů - je známa jen $\mathrm{z}$ archivních záznamů. ${ }^{48}$ Dochovala se pouze výzdoba čtyř vstupních dveř́i do tř́ zámeckých traktů postavených do roku 1714. Vedle spiše řemeslné výzdoby dvojice dveří bočních křídel Ordensbau a Riesenbau se jednalo hlavně o reliéfy na dvou protilehlých dveřích v ose jižního a severního průčelí Fürstenbau.$^{49} \mathrm{~K}$ jejich vytvoření se pražský umělec zavázal smlouvou z 25 . ŕína 1711.50

Dveřní křídla dvou totožných dubových dveří, jež měly být podle původního záměru pozlaceny ${ }^{51}$ jsou od sebe oddělena oválným sloupkem, ozdobeným akantovými listy, které jsou staženy páskou. ${ }^{52}$ Každé z kř́del se dělí na čtyři úseky, mezi nimiž vynikají dvě pole s reliéfní řezbářskou výzdobou. Střední obdélníkové pole je zasazeno do profilovaného rámu a jeho výzdobu tvoří armatura s přilbou, štítem a zkříženými meči a kopími. Nad bronzovým klepadlem v podobě lví hlavy a kruhu ovinutého hadem je vyřezán obličej divého muže s plnovousem a látkovými křidélky po stranách hlavy. Do nejvýše umístěného pole je vložen masivní vavř́nový věnec obklopený listovím, jehož vnitřní plochu vyplňuje mohutná hlava řvoucího lva. Symbol lva v této době ještě nebyl součástí württemberského zemského znaku - tou se stal až počátkem 19. století. Jeho význam tak v tomto prŕpadě není heraldický, ale spíše apotropaický. Militaria se do výzdoby zámku promítají opakovaně a vyjadřují reprezentaci vévody Eberharda Ludwiga jako úspěšného vojevůdce a ochránce svěřené země, jenž ve své vojenské kariéře postoupil nejvýše k hodnosti vrchního velitele říšské rýnské armády.

Quitainerovy reliéfy, označené Fleischhauerem za neobratné a nemoderní, ${ }^{53}$ vycházejí $\mathrm{z}$ tradice pražského řezbářství druhé poloviny 17 . století, $\mathrm{k}$ níž se hlásí svou důraznou plastičností a realistickým řezbářským projevem, zde nadto okořeněným Quitainerovým sklonem $k$ výrazové drsnosti. Bizarní ornamentika se spletí motivů a hojně využívaným listovým ornamentem mohla být ovlivněna i soudobými francouzskými grafickými předlohami - např́iklad těmi z produkce rodiny Le Pautre, které během své cesty do Paříže v dubnu 1709 shromáždil dvorní maršálek Forstner. ${ }^{54}$

${ }^{48}$ Hauptstaatsarchiv Stuttgart, Landesschreiberei-Rechnungsbuch Bd. 194, fol. 413, Potvrzení o platbě O. F. Quitainerovi za čtyři stolky (,tableaux“) ze dne 27. 7. 1710. Hauptstaatsarchiv Stuttgart, Landesschreiberei-Rechnungsbuch Bd. 194, fol. 413, Potvrzení o platbě O. F. Quitainerovi za hrací stolek a rámy (?). Hauptstaatsarchiv Stuttgart, Rentkammerakten, Bü 2222, Protokoll Baudeputation vom 17. Juli 1713, Účet O. F. Quitainera za řezbářské práce (Spiegelrahm).

49 Účet na výzdobu dveři Ordensbau vystavil Quitainer 14. listopadu 1712. Požadovaná částka $104 \mathrm{zl}$. byla později snížena na 90 zl. Výzdoba těchto dvoukřídlých, osově symetrických dveří je řemeslnou prací bez prvkủ individuální invence. Jejím nejvýraznějším motivem je vévodská čapka nad velkou mušlí v horní části obou kř́́del. Hauptstaatsarchiv Stuttgart, Rentkammerakten, Bü 2222, Protokoll Baudeputation vom 14. November 1712, Účet O. F. Quitainera za vyřezávané dveře. Protějškové dveře kř́dla Riesenbau jsou zcela identické. Vznikly pravděpodobně při dokončování tohoto objektu v roce 1714, na jehož výzdobě se Quitainer podílel.

50 Hauptstaatsarchiv Stuttgart, Kirchenrat, verschlossene Registratur, Bü 813, nečíslováno (po čísle 26), Smlouva mezi J. F. Nettem a O. F. Quitainerem, týkající se dvou dubových vstupních dveří.

51 Fleischhauer, Barock im Herzogtum (pozn. 2), s. 150.

52 Hořák (pozn. 6), s. 120-121.

53 Fleischhauer, Barock im Herzogtum (pozn. 2), s. 150.

54 Srov. Seeger, Vienna, Prague (pozn. 9), s. 196. 
V roce 1712 se měl Quitainer do dokončovacích prací ve Fürstenbau zapojit ještě výrazněji. Honorář ve výši 900 zlatých, sjednaný v jeho smlouvě z přelomu května a června tohoto roku, ${ }^{55}$ naznačuje, že náplní kontraktu měl být větší počet sochařských realizací. K naplnění podmínek smlouvy ale nakonec nedošlo, protože pražský mistr v záŕí 1712 ztratil v Ludwigsburgu postavení hlavního sochaře. Ve Fürstenbau stihl už jen výzdobu portiku, kterou mu připsal Werner Fleischhauer. ${ }^{56}$

Obdélný portikus je situován na stř̌ední ose jižního průčelí a dosahuje výše prvního patra Fürstenbau. Jeho hlavní portál, př́stupný z nádvoří čtyřmi kamennými stupni, je akcentován dvojicí předsazených sloupů toskánského řádu, jejichž osy prodlužuje dvojice vysokých kamenných váz na nárožních piliřích balkonu. Na okosená nároží průčelí portiku navazují úseky nízké balustrády na půdorysu výseče oválu.

Okosená nároží portiku zdobí výškově orientované reliéfní pásy ve vpadlých zrcadlech. Oba reliéfy jsou takřka identické, liši se však kvalitou zpracování. Reliéf na pohledově levé straně vyniká plnějšími objemy, diferencovanější strukturou povrchů a větším citem pro jadrně realistický detail. Rutinněji zpracovaný reliéf na protilehlé straně portiku je pravděpodobně pozdější kopií. Ikonograficky se tyto reliéfní pásy podobají řezbám, jimiž Quitainer vyzdobil vstupní dveře Fürstenbau. Stejně jako tyto práce ve dřevě kombinují štukové reliéfy různé druhy mečů a další prvky zbroje. Atributy jako hlava Medúsy na štítu nebo sova usazená na vrcholu antikizující přilbice odkazují k Pallas Athéně. Kompozice vrcholí hlavou lva posazenou na kmeni stromu. Pallas Athéna jako bohyně moudrosti, statečnosti a spravedlivě vedené války je tak spojena se lvem jako ztělesněním síly.

Dvě vysoké a bohatě zdobené vázy na nárožích balkonu lze na základě stylové příbuznosti jejich výrazově neutrálních maskaronů s obdobnými dekorativními prvky na fasádě Fürstenbau spojit s dílnou Sebastiana Zimmermanna. Reliéfní výzdoba dvou menších nálevkovitých váz na nárožích přízemní balustrády podél portiku naopak odpovídá Quitainerovu sochařskému naturelu. Tyto vázy zdobí čabraky, akantové listy, voluty, drobné maskarony a figurální reliéfy na náměty antické mytologie. Na přední straně vázy na pravé straně portiku se nachází reliéf s Herkulem zabijejícím nemejského lva. Hrdina napřahuje kyj a zároveň přes rameno svalnaté ruky hledí na šelmu pod sebou. Spojení tohoto kompozičního principu s propracovaným svalstvem napnuté ruky je pro Quitainera charakteristické. Reliéf na druhé straně vázy představuje antického vojáka v přilbě s pery. Podle vyobrazené jabloně jde o Herkula v zahradě Hesperidek. Na přední straně druhé vázy bojuje muž v antické zbroji s okř́íleným drakem. Mohlo by se jednat o boha Apollóna při střetu s drakem Pýthónem, a to tím spíše, že protěǰ̌i reliéf zobrazuje Apollónovou sestru Artemis s atributy luku, šípu a loveckého psa.

Reliéfní výzdoba portiku i obou kamenných váz odráží významový posun ve vnímání a prezentaci ludwigsburského zámku, jenž se z původního místa odpočinku a loveckých radovánek postupně změnil v nové mocenskopolitické centrum. Politizace stavebního podniku přitom začala nabývat na intenzitě právě v období poslední fáze války o španělské dědictví před uzavřením Rastattského míru v roce $1714 .{ }^{57}$

55 Hauptstaatsarchiv Stuttgart, Rentkammerakten, Bü 2222, Protokoll Baudeputation 3. Juni 1712, Informace o přeposlání smlouvys O. F. Quitainerem (sochařské práce ve Fürstenbau za 900 zl.).

56 Fleischhauer, Barock im Herzogtum (pozn. 2), s. 149-150.

57 Srov. Merten (pozn. 7), s. 25. 


\section{Alegorické sochy ve vestibulu Ordensbau a konec první etapy Quitainerova působení v Ludwigsburgu}

Po dokončení hrubé stavby hlavní zámecké budovy Fürstenbau na podzim roku 1708 začaly hned v následující stavební sezóně zednické práce na západním křídle, zvaném Ordensbau. Tento trakt byl koncipován jako pavilon obdélného půdorysu, jenž byl v pravém úhlu volně přisazený $\mathrm{k}$ Fürstenbau, s nímž jej v roce 1711 spojila dvoupodlažní nárožní arkáda. Práce na jeho vnitřní výzdobě začaly v roce 1712 za účasti Ondřeje Filipa Quitainera, který dne 4. července předložil cenový odhad na pískovcové sochy Caritas („Liebe“) a Prudentiae („Vorsichtigkeit“), do vstupního prostoru za vchodovými dveřmi..$^{58}$ Obě sochy se jako jedny z mála jeho realizací $\mathrm{v}$ Ludwigsburgu zachovaly na pủvodním místě a ve své původní metalizující barevnosti, imitující bronz či měd.

Obě alegorické postavy jsou umístěny ve vysokých nikách podél ústí krátké chodby vedoucí ke schodišti. Dř́ky jejich identických podstavců mají konvexně vypjatou čelní stěnu, jsou rámovány nakoso osazenými úzkými pilastry a zakončeny oblamovanou a předsazenou římsou s jemným profilováním, které je sladěno s profilací vodorovných lisenových rámců přilehlých stěn. Na čelní stěně obou podstavců se nachází reliéf s motivem mušle, rozvilin a festonu $\mathrm{z}$ růžových květů, na němž je posazena korunka. Okrové zbarvení dříku podstavce vytvárí chromatický přechod mezi šedými lisenami stěn a hnědozlatou barevností alegorických soch.

Socha Caritas vychází z Ikonologie Cesara Ripy, v jejímž vydání z roku 1645 je tato alegorie popsána jako žena $\mathrm{v}$ červených šatech, která drží v pravé ruce planoucí srdce jako symbol čistého citu a duše obrácené $\mathrm{k}$ Bohu ${ }^{59} \mathrm{Na}$ levém předloktí nese Caritas podle Ripy dítě odkazující na Ježíšova slova: „Amen, pravím vám, cokoliv jste učinili jednomu z těchto mých nepatrných bratří, mně jste učinili“ (Mt. 25, 40). Quitainerova Caritas si tiskne k prsu nahé dítě, jež leží po jejím levém boku na bohatě vyšívané podušce, spočívající na štíhlém sloupku s konkávně probranými boky a římsovou hlavicí. Obdobnou kompozici se stojící dospělou postavou vedle podstavce s (téměř) nahým dítětem zvolil v roce 1707 Quitainerův švagr Jan Oldřich Mayer na sousoší sv. Antonína Paduánského z Karlova mostu. ${ }^{60}$ Quitainer stejně jako Mayer pracuje s motivem lukovitého prohnutí těla hlavní postavy proti vertikále sloupku. Uplatňuje rovněž Mayerův oblíbený skladebný vzorec drapérie, spočívající v kontrastu mezi hustě nakupenými záhyby látky na nosné noze a napjatým šatem na klenuté volné noze. Ve srovnání se svým př́edchůdcem se ale Quitainer více soustředil na vyjádření láskyplného a pečujícího vztahu. Uvolněný postoj Caritas s charakteristickým zhoupnutím v bocích, korpulentnost její postavy, úsměv v její široké tváři - to vše navozuje atmosféru přijímajícího mateřství, již podtrhují dekorativní detaily, jako je polštář s vyšíváním a střapcem nebo diadém s planoucím srdcem.

58 Hauptstaatsarchiv Stuttgart, Rentkammerakten, Bü 2222, Protokoll Baudeputation vom 4. Juli 1712, Informace o cenovém odhadu týkajícím se soch Caritas a Prudentiae (Liebe und Vorsichtigkeit). Quitainer za tyto sochy požadoval $300 \mathrm{zl}$., z nichž mu bylo vyplaceno $250 \mathrm{zl}$.

59 Cesare Ripa, Iconologia per Cesare Ripa Perugino, cavallier di SS Mauritio et Lazaro. Divisa in tre libri. Ampliata dal. sig. cav. Gio. Zaratino, castellini Romano, Venetia 1645, s. 85. Srov. také český výbor z tohoto díla: Cesare Ripa, Ikonologie, Praha 2019, s. 116.

${ }^{60} \mathrm{~K}$ tomuto sousoší srov. Blažíček, Sochařství baroku (pozn. 17), s. 104. 
Protějšková Prudentia opět volně vychází z Cesara Ripy. Ten ve svém slavném kompendiu líćí tuto ctnost jako ženu se dvěma tvářemi a zlatou přilbicí, zrcadlem, holí obtočenou hadem či rybou a př́padně i dalšími atributy. ${ }^{61}$ Quitainerův přístup k této nabídce je opět výběrový. Představuje danou ctnost jako prostovlasou mladou ženu s odhalenými ňadry. Postava drží v pravé ruce malé oválné zrcadlo, zastupující kontemplaci a myšlení obrácené do vlastního nitra. Mezi prsty levé ruky se Prudentii proplétá had jako symbol moudrosti. ${ }^{62}$

Antikizující pojetí ženské postavy s vysoko nasazeným pasem, šikmými vlásečnicovými záhyby látky kolem linie přepásání a s prríčným pruhem přetočeného pláště, jenž na pravé straně vybíhá v rozevlátý cíp, vychází z řezby sv. Heleny na hlavním oltáři pražského křižovnického kostela sv. Františka. ${ }^{63}$ Quitainer tuto vynikající práci svého současníka Matěje Václava Jäckela z období po roce 1700 bezpochyby znal. Není také vyloučeno, že s Jäckelem udržoval i osobnější vztahy, nebot oba sochaři se dlouhodobě přátelili s pražským kameníkem Janem Oldřichem Mannesem a jeho rodinou. ${ }^{64}$ Ve srovnání s Jäcklovou sv. Helenou působí Quitainerova alegorie toporněji, a to zejména proto, že postrádá její ladně krouživý, stoupavý pohyb. Usměvavý obličej Prudentiae je nadto vzdálen vážné klasicizující tváři Jäckelovy sv. Heleny a navazuje na typiku Quitainerových byst z Březnické brány na Svaté Hoře (1707). ${ }^{65}$

Německý badatel Daniel Schulz nedávno připsal pražskému sochaři další alegorickou postavu ze sbírek zámecké rezidence v Ludwigsburgu. ${ }^{66}$ Okolnosti vzniku této pískovcové sochy ani její původní umístění nejsou známy ${ }^{67}$ Ikonograficky, materiálově i svým kompozičním i modelačním pojetím se řadí k sochám z vestibulu Ordensbau a lze ji tak datovat kolem roku 1712. Představuje majestátně vyhlížející ženu středního věku, plných tvárí a korpulentní postavy, která je oděna v bohatě nabírané róbě s dlouhým cípem pláště přehozeným přes předloktí pravé ruky. Slavnostně působící šat sklouzává dámě z pravého ramene a částečně odhaluje její hrud. Volná levá noha se téměř v celé své délce klene pod napjatou látkou. Žena má na hlavě routový věnec, levou rukou si přikládá $\mathrm{k}$ hrudi řetízek, symbolizující návaznost dobrých skutků, v pravé ruce drží sošku Pallas Athény a u nohou jí sedí pelikán, odkazující ke ctnosti sebeobětování. Podle těchto atributů lze postavu určit jako Benefitio (Dobrotivost). ${ }^{68}$

Ikonografická koncepce všech tří alegorií opět z jiného úhlu vyjadřuje principy vladařské reprezentace Eberharda Ludwiga a glorifikuje jej jako panovníka oplývajícího

61 Cesare Ripa, Iconologia (pozn. 54), s. 508. Cesare Ripa, Ikonologia (pozn. 54), s. 376.

62 Nejednalo se ovšem o sochařuov osobní výběr. Těmito atributy je Prudentia vybavena již např́iklad na náhrobku Ludvíka XII. a Anny Bretaňské (1515) v katedrále v St. Denis.

63 Nejnověji k tomuto oltáři a jeho sochařské výzdobě srov. Jana Tischerová, Matěj Václav Jäckel. Sochař českého baroka 1655-1738, Praha 2013, s. 193-198.

64 Ke Quitainerovým osobním a přátelským vztahům s Mannesem srov. Hořák (pozn. 6), s. 60.

65 Nejnověji k této Quitainerově nejstarší doložené zakázce srov. Hořák (pozn. 6), s. 113-115. Zde i odkazy na starší literaturu.

66 Schulz (pozn. 41), s. 37.

67 Při místní obhlídce v dubnu 2017 se mi sochu nepodařilo dohledat. Podle dodatečné informace konzervátorky Iris Henke ze stavebního úřadu v Ludwigsburgu (Vermögen und Bau Baden-Württemberg - Amt Ludwigsburg) se socha nachází v zadním zámeckém dvoře blízko Matyldiny zahrady v malém zastřešeném skladišti soch (mail z 22. 1. 2019). Potvrzeno bylo rovněž, že se jedná o pískovcovou sochu. Fotografii publikoval D. Schulz. Schulz (pozn. 41), s. 38, obr. 5.

68 Cesare Ripa, Iconologia (pozn. 54), s. 72. Cesare Ripa, Ikonologia (pozn. 54), s. 45. S touto alegorií již sochu ztotožnil D. Schulz. Srov. Schulz (pozn. 41), s. 37. 
křestanskou láskou k bližnímu a silou uvážlivého rozumu. Prostřednictvím personifikace Benefitia se soškou Pallas Athény je vévoda nadto prezentován jako podporoval věd a umění. ${ }^{69}$

Po dokončení zakázek pro Ordensbau a v průběhu práce na výzdobě Fürstenbau došlo v Quitainerově životě k nečekanému zvratu. Dne 10. záŕí 1712 dostal Nette z dvorské stavební deputace př́kaz k sochařovu propuštění. ${ }^{70}$ Podle vydaného dekretu měl Quitainer dokončit rozpracované zakázky a další práce přenechat Sebastianovi Zimmermannovi, jejž před lety nahradil, a Giorgiovi Ferrettimu, který v Ludwigsburgu působil od účetního roku 1711/1712. ${ }^{71}$ Ještě v září 1712 přijal Quitainer honorář za čtveřici nedochovaných putti, zahrnutých do Ferrettiho vyúčtování. ${ }^{72} \mathrm{Z}$ listopadu téhož roku pochází účet za výtvarně neutrální řezbářskou výzdobu hlavních vchodových dveří Ordensbau. ${ }^{73}$ Poté pravděpodobně náš sochař svůj pobyt ve Württembersku na určitou dobu přerušil. ${ }^{74}$

$\mathrm{Z}$ dochovaných pramenů nevysvítá, jaké důvody stály za jeho náhlým propuštěním. ${ }^{75}$ Protože však v Ludwigsburgu působil i v následujících dvou letech a nadále zde byl pověřován umělecky náročnými a prestižními úkoly, nemusela být příčinou nespokojenost s jeho sochařskými výkony. Mohlo se kupř́kladu jednat o důsledek chronicky neuspokojivého stavu württemberských státních financí a s tím souvisejících úsporných opatření, které již v roce 1709 připravily o místo dvorního sochaře Zimmermanna.

\section{Výzdoba balustrády čestného dvora}

V průběhu roku 1713 pokračovaly stavební práce na východním zámeckém křídle, později zvaném Riesenbau, po jehož dokončení vznikla dodnes zachovaná sestava tři zámeckých budov na půdorysu písmene „U“. V létě 1713 byla na spojnici obou protilehlých křídel postavena balustráda vymezující plochu čestného dvora. ${ }^{76}$

Půdorysný průběh této později odstraněné balustrády je znám z dobových stavebních plánů a vedut. ${ }^{77} \mathrm{~V}$ kontrastu k plochému průčelí Fürstenbau byla konvexně vypjata

69 Tuto interpretaci sochy navrhl již D. Schulz. Srov. Schulz (pozn. 41), s. 37.

70 Hauptstaatsarchiv Stuttgart, Rentkammerakten, Bü 2222, Protokoll Baudeputation vom 10. September 1712, Dekret o propuštění O. F. Quitainera ze služeb.

71 Fleischhauer, Barock im Herzogtum (pozn. 2), s. 149.

72 Huptstaatsarchiv Stuttgart, Rentkammerakten, Bü 2222, Protokoll Baudeputation vom 14. November 1712.

73 Hauptstaatsarchiv Stuttgart, Rentkammerakten, Bü 2222, Protokoll Baudeputation vom 14. November 1712. Účet O. F. Quitainera za vyřezávané dveře.

74 Dne 31. ř́ína 1713 křtil v malostranském kostele sv. Mikuláše dceru Markytu. Záznam o tomto křtu je prvním dokladem jeho pobytu v Praze po roce 1709. Srov. Antonín Podlaha, Materiálie k slovníku umělců a uměleckých řemeslníků v Čechách, in: Památky archeologické XXVII, 1915, s. 179. Již dříve v tomto roce (27. 4. 1713) mu byl v jeho rodném Frýdlantu vystaven zachovací list. Snad již tehdy uvažoval, že se trvale usadí v Praze a požádá zde o městská práva, což nakonec učinil až v roce 1718. Blíže k tomuto tématu srov. Hořák (pozn. 6), s. 32-33, 35.

75 „Fiat Decret an Obrist Lieutenant Nette, den Bildhauer Quittainer abzudanckhen, doch daß Er das, waß unter der arbeit Er aiß machen möge, und solle die Bildhauerarbeit den Zimmermann und Feretti überlassen werden. Hauptstaatsarchiv Stuttgart, Rentkammerakten, Bü 2222, Protokoll Baudeputation vom 10. September 1712, Dekret o propuštění O. F. Quitainera ze služeb.

76 Srov. Fleischhauer, Barock im Herzogtum (pozn. 2), s. 149; Merten (pozn. 7), s. 27; Schulz (pozn. 43), s. 32. Podle D. Schulze byla balustráda odstraněna v raném 19. století.

77 Srov. Merten (pozn. 7), s. 10, 13. 
směrem k jihu a její střed, osově svázaný se zámeckým průčelím a centrální komunikací obou zahradních parterů, prolamovala brána s mříží. Obě symetrická ramena balustrády sestávala z konvexně vypjatého oblouku po stranách průjezdu, středního, dvakrát zalomeného úseku a krátkého konkávního zakončení před postranními průchody u obou protilehlých zámeckých kř́ídel.

Levé i pravé kř́idlo balustrády zdobily figurální plastiky: Múza, Venuše, Fáma, Mars, Herkules a Merkur, a dále čtyři ozdobné kamenné vázy. ${ }^{78}$ Pilíře průjezdu korunovaly dvě přilbice $s$ vojenskými trofejemi. ${ }^{79}$ Všechny tyto sochařské prvky byly pro zvýšení účinku pozlaceny. ${ }^{80}$ Podle Forstnerova dopisu vévodovi z 12 . června 1713 byly v té době dokončeny téměř všechny podstavce a Quitainer pracoval na sochách. ${ }^{81}$ Vytesání ozdobných váz bylo svěřeno Zimmermannovi. ${ }^{82}$ Objednána již měla být i železná mř́ǐz. ${ }^{83}$ Z Quitainerova vyúčtování vyplývá, že v roce 1714 dodal ještě dva orly či spíše orlice (Adler) se štíty na malé kašny u balustrády. ${ }^{84}$

S výzdobou balustrády můžeme spojit čtyř̀i Quitainerovy plastiky ze zámeckého lapidária, z nichž nejvýraznější je Herkules $v$ kưži nemejského lva. ${ }^{85}$ Hrdina se podobně jako Meleagros vyznačuje atletickou postavou a vypracovaným, tentokrát však sušeji modelovaným svalstvem. Je zachycen v klidném postoji s podloženou levou nohou, opřený o pahýl stromu za svými zády. Přes hlavu má přehozenou lví kůži a levou rukou si přidržuje sukovitý kyj položený na rameni. V ostrém úhlu ohnutá a za záda založená pravice je citací téhož motivu antické sochy Herkula Farnese, nacházející se počátkem 18. století v již zmíněném Palazzo Farnese, v místnosti zvané Camerino Farnese, kde ji obklopovaly carracciovské fresky. ${ }^{86}$ Inspirace je to však velmi volná a $\mathrm{k}$ našemu sochaři musela proniknout prostřednictvím dalších, blíže neurčených předloh, nebot jeho hrdina se na rozdíl od antického předobrazu neopírá o kyj zahalený ve lví kůži a také postavení jeho nohou a celková pohybová koncepce jsou odlišné.

Podmračená a jakoby sražená tvář se zježeným knírem přes ústa, skobovitým nosem, vybouleninami bohatě promodelovaných tváří a svraštělým obočím je vzdálena antickému kánonu a vyznačuje se seversky drsnými rysy na hranici karikatury. V kontextu soudobého záalpského sochařství má tato expresivní stylizace opět blízko k Andreasi Schlüterovi, konkrétně k jeho Umírajícím válečníkưm z klenáků ve vnitřním dvoře berlínské Zbrojnice (Zeughaus) z období po roce 1696. Rovněž zde by však mohlo jít nanejvýš

78 Ibidem.

79 Ibidem.

80 Ke zlacení soch srov. Merten (pozn. 7), s. 27. Podle Fleischhauera tyto sochy „,blauweiß und Leibfarb bemalt wurden, so wie wir uns die gesamte Steinplastik bemalt vorzustellen haben, wenn sie nich vergoldet wurden. Fleischhauer, Barock im Herzogtum (pozn. 2), s. 149. Mertenovu údaji o pozlacení soch nasvědčují zbytky polychromie na obou dochovaných ženských postavách, jimž věnuji pozornost v rámci dalšího výkladu.

81 Hauptstaatsarchiv Stuttgart, Geheimer Rat, Bü 3032, Nr. 83, Dopis vrchního maršálka G. F. Forstnera vévodovi Eberhardu Ludwigovi.

82 Ibidem.

83 Ibidem.

84 „Zween Adler mit schildten auf die bronnen an der Gallerie.“ Za tuto práci obdržel 120 zl. Srov. Hauptstaatsarchiv Stuttgart, Rentkammerakten, Bü 2222, Protokoll Baudeputation vom 25. Mai 1714, Výčet sochařských prací, realizovaných O. F. Quitainerem v „Riesenbau“.

85 Srov. Hořák (pozn. 6), s. 183-184.

86 Srov. Wittkower, Art and Architecture (pozn. 34), 35-36. Nyní se socha nalézá v Národním archeologickém muzeu v Neapoli. 
o volnou inspirační vazbu. Typový realismus Herkulovy tváře není spojen s vyjádřením žádného jednoznačně uchopitelného prožitku. Jak přitom ukázala nedávná analýza Fritz-Eugena Kellera, podobu Schlüterých hrdinů zásadním způsobem ovlivnila obrazová typologie lidských temperamentů a afektů, vypracovaná nedlouho před jejich vznikem Charlesem Le Brunem, a inspiroval ji také tragický patos sousoší Láokoónta a jeho synư a dalších děl helénského sochařství. ${ }^{87}$

Také socha Marta se svým tělesným kánonem vyznačuje antikizujícím pojetím. ${ }^{88}$ Bůh války je vykreslen jako římský legionář v krátké suknici a anatomicky tvarovaném hrudním krunýři. Na hlavě má přilbicí s bujným chocholem, v dlani pravé ruky drží vojevůdcovskou hưl, v podpaží levé ruky má oválný štít s reliéfem orlice a u nohou mu leží barokní vojenský buben. Mírně zvlněná tělesná osa, motivovaná nakročením, ústí ve šlachovitý krk. Realistické pojetí hlavy a obličeje se i v tomto případě vymyká klasickému ideálu. Portrétně prohloubená typika energické tváře s naléhavým pohledem hluboko zasazených očí předjímá Quitainerovu vrcholnou řezbu sv. Václava z pražského kostela sv. Tomáše z let 1720 až 1721 .

Mezi figurální plastiky z bývalé dvorní balustrády by mohly náležet i dvě ženské postavy, prezentované v lapidáriu rovněž ve skupině Quitainerových děl. Ikonografie sochy označené na popisce jako Atalanta je nejasná, nebot postava postrádá předmětné atributy - snad je pưvodně držela v nyní chybějící pravé ruce nebo v sevřené dlani levé ruky. ${ }^{89}$ Dochované zbytky podkladové cihlově červené barvy a zlacení na zádech a drapérii naznačují, že by se mohlo jednat o jednu z pozlacených plastik na balustrádě. O tomto účelovém určení svědčí i výška sochy, její nápadně antikizující manýra, štíhlý tělesný kánon, jenž je ve shodě s ostatními sochami balustrády, a nadprůměrná úroveň zpracování, odpovídající prestižnímu charakteru úkolu. Je-li tento předpoklad správný, máme zde co dočinění s Múzou nebo Fámou.

Jako jediná z Quitainerových soch ze zámeckého lapidária je tato postava zachycena v chůzi či běhu. Její prudké nakročení by skutečně mohlo odpovídat bájné běžkyni Atalantě, jež se podobně jako Meleagros připojila $\mathrm{k}$ účastníkům lovu na kalydónského kance. Stejně tak by ale mohlo jít o Fámu, jíž „žádná z př́ǐer se rychlostí nemůže rovnat, poněvadž rychlostí roste a chůzí nabývá síly“. ${ }^{00}$ Socha však rozhodně nepředstavuje "příšeru“, ale naopak sličnou štíhlonohou ženu, a muselo by se tedy jednat Fámu v úloze zvěstovatelky věčné slávy. Natočení hlavy a pohled směřující vpravo naznačují, že postava mohla stát na balustrádě vedle soch Herkula a Marta a hlásat tak světu jimi ztělesňované činy a ctnosti.

Poslední z uvedené čtveřice plastik z lapidária je Venuše Kallipygos. ${ }^{91}$ Také na jejím povrchu se dochovala rezidua podkladové barevné vrstvy a zlacení. Sochař se v tomto případě nechal inspirovat stejnojmenným římským mramorem, jenž podobně jako výše uvedený Herkules pochází ze sbírek rodu Farnese a na začátku 18. století byl také chován

87 Autor rovněž upozorňuje na nepřesnost tradičního označení Umírající válečníci, nebot' ve skutečnosti se pravděpodobně jedná o utaté hlavy nepřátelských válečníků. Srov. Fritz-Eugen Keller, Die Schlusssteine der Bogen am Erdgeschoss des Zeughauses, in: Hans-Ulrich Kessler (ed.), Andreas Schlüter und das barocke Berlin, Berlin 2014, s. 136-167.

88 Srov. Hořák (pozn. 6), s. 184-185.

89 Ibidem, s. 181-183.

90 Publius Vergilius Maro, Aeneis, Praha 1933, s. 177 (překl.: Otmar Vaňorný).

91 Srov. Hořák (pozn. 6), s. 186-187. 
v Palazzo Farnese. ${ }^{92}$ Povědomí o tomto proslulém a napodobovaném mistrovském díle antického sochařství se šírilo prostřednictvím grafických předloh a jeho kopie vytvářeli i sochaři působící ve službách Ludvíka XIV. ${ }^{93}$ Naskýtající se hypotéza o možné hlubší inspirační vazbě mezi figurální výzdobou ludwigsburské dvorní balustrády a farneskou sbírkou tak vzhledem ke známosti uvedené předlohy postrádá pevnější opory.

Pozdně římská socha Venuše Kallipygos je jedním z nejsmyslnějších (částečných) ženských aktů v dějinách evropského sochařství. Představuje mladou ženu ohlížející se přes rameno a klouzající pohledem po křivkách svého postupně odhalovaného těla. V Quitainerově podání byl tento erotický tón potlačen již tím, že sebevzhlíživý „gaze“ nahradil pohled namířený před sebe. Venuše je nadto zobrazena v záklonu s nepřirozeně prohnutými zády a vzepjatou pravou paží. Neosobní modelace dodatečně doplněné hlavy zaostává za kvalitou typového realismu Quitainerových originálů.

Ikonografická koncepce balustrády odkazovala ke dvěma hlavním významovým rovinám reprezentace württemberského vévody jako vzorného křest’anského panovníka. Tou první byla oslava Eberharda Ludwiga v roli kulturního mecenáše a jejím výrazem byly postavy Merkura, Venuše a Múzy. Přítomnost válečných trofejí a jejich prominentní postavení na pilírích vstupní brány však naznačují, že důraz byl kladen především na mocenskopolitickou významovou vrstvu, k níž vedle explicitních militarií náležely i symbolické postavy Herkula a Marta. Do stejného interpretačního rámce náležela i dvojice orlic se štíty na kašnách vedle balustrády. Symbol orlice nechal totiž vévoda v roce 1705 zařadit mezi württemberské heraldické znaky v reakci na svůj spor s hannoverským knížectvím o právo na titul nositele Ř́šského bojového praporce (Reichssturmfahne), ${ }^{94}$ od jehož získání si sliboval posílení svého postavení a vlivu v ř́iši. O politických konotacích konečně vypovídají i odkazy na starověký Řím a jeho imperiální tradici, které můžeme vnímat na pozadí volby předloh a patrně záměrného prríklonu k antikizující manýře uvedených figurálních plastik.

\section{Zámecké kř́́dlo Riesenbau a epilog Quitainerova uměleckého působení v Ludwigsburgu}

V závěru roku 1713 byla dokončena hrubá stavba východního zámeckého křídla, podle Quitainerových Atlantů dnes zvaného Riesenbau. V jeho prvním poschodí měl podle původních plánů vzniknout dvorní kostel, ale již v létě 1711 bylo rozhodnuto, že bude nahrazen reprezentativním sálem, jenž měl sloužit jako místo setkávání a společných bohoslužeb příslušníků řádu svatého Huberta. ${ }^{95}$ Zpočátku zamýšlený chrámový prostor i následně realizovaný slavnostní sál měl být z př́izemí přístupný okázalým schodištěm. ${ }^{96}$ Hlavní podíl na vytvoření jeho sochařské výzdoby - na vytesání pískovcových

92 Nyní je stejně jako Herkules Farnese součástí sbírek Národního archeologického muzea v Neapoli. Srov: http://www.museoarcheologiconapoli.it/en/sculptures/, vyhledáno 13. 4. 2020.

93 Námět zpracovali mj. Jean-Jacques Clérion nebo François Barois.

94 Srov. Uhland (pozn. 1), s. 237-238.

95 Srov. Merten (pozn. 7), s. 23.

96 Do koncepce objektu bylo zahrnuto dodatečně a objevuje se až ve druhém ze tř́ dochovaných stavebních plánů. Srov. Michael Wenger, Ludwigsburg als Residenz des Hubertus Jagd-Ordens von 1702, in: Staatliche Schlösser und Gärten Baden-Württemberg (pozn. 1), s. 110-111. 
soch čtyř Atlantů podpírajících schodiště, Pallas Athény v nice na podestě a dvou dívčích byst v oválných průzorech na čelní stěně - připadl Quitainerovi. ${ }^{97}$ Plastickou výzdobu měly doplnit dvě sfingy s putti na hřbetech, jež byly zadány Zimmermannovi. ${ }^{98}$ Atlanti a busty jsou bíle štafírováni na zpo̊sob mramoru, povrchová barevná úprava obou sfing a Pallas Athény imituje bronz. ${ }^{99}$

Inspirací pro architektonické řešení schodiště i jeho sochařskou výzdobu se staly soudobé vídeňské vzory. Zejména se jednalo o schodiště paláce Trautson z let 1710 až 1712 a schodiště zimního paláce Evžena Savojského, budovaného od roku 1697. ${ }^{100}$ Oba tyto paláce byly postaveny podle návrhů Johanna Bernharda Fischera z Erlachu a sochařská výzdoba jejich slavnostních schodišst je doložena jako práce Giulia Giulianiho (palác prince Evžena), popřípadě mu připsána (palác Trautson).

Svou prostorovou dispozicí má ludwigsburské schodiště blíže k paláci Trautson, nebot’ v obou případech vynáší čtveřice Atlantů oblouky klenby nad první podestou a v sochařské výzdobě se uplatňuje motiv sfing spočívajících na zábradlí vstupního ramene. V paláci Trautson nicméně navazuje na uvedenou podestu další př́ímý úsek schodů, jenž vede $\mathrm{k}$ druhé podestě. Teprve zde se schodiště větví ve dvě ramena. V Ludwigsburgu naproti tomu dochází k větvení již na první podestě a obě boční schodištní ramena ústí př́mo do prostoru mezi dvěma páry Atlantů. Za podestou je již jen jedno pole plackovité klenby a poté následuje zadní stěna s nikou a dekorativně pojatou sochou na střední ose, takže místo prosvětleného otevřeného prostoru, jenž ve vídeňském paláci dává v dlouhých pohledech vyniknout monumentalitě schodiště, vzniká v zadním plánu v podstatě intimní zákoutí.

Atlanti z obou výše zmíněných vídeňských paláců jsou organicky začleněni do tektonických vztahů schodištní konstrukce, přičemž v paláci Evžena Savojského jsou odvážně vloženi do volného prostoru a v paláci Trautson jsou situováni na architektonických podstavcích a tvoří střední článek nosných pilírư. Naproti tomu v Riesenbau spočívají Atlanti na nízkých nearchitektonických soklech a podpírají stlačené oblouky klenby, jejichž paty jsou od jejich hlav odděleny jen drobnými volutami. Toto rozvolnění strukturální vazby

97 Podle vyúčtování z 24. 5. 1714 obdržel Quitainer celkem 800 zl. za čtyři Atlanty o výšce deseti stop, $125 \mathrm{zl}$. za Athénu se štítem Medúzy a 60. zl. za dvě poprsí včetně podstavců. Do vyúčtování byly dále zahrnuty dvě orlice se štíty na kašny při dvorní balustrádě v ceně $120 \mathrm{zl}$. a čtyři „antické“ vázy na fasádu Riesenbau v ceně 300 zl. Srov. Hauptstaatsarchiv Stuttgart, Rentkammerakten, Bü 2222, Protokoll Baudeputation vom 25. Mai 1714, Výćet sochařských prací, realizovaných O. F. Quitainerem $v$ „Riesenbau“. Podle Quitainerova účtu z následujícího dne mělo být sochaři vyplaceno o $150 \mathrm{zl}$. více, než činí součet uvedených částek, tzn. 1555 zl. Honorář byl snížen na 1400 zl. Srov. Hauptstaatsarchiv Stuttgart, Geistliche Ämterrechnungen, Bü 8736, Jahresausgaben 1714-1715, fol. 172, Účet O. F. Quitainera za sochařské práce v „Riesenbau“. Na dodávkách kamene pro tuto stavební etapu se podílel pražský kameník a Quitainerův dobrý známý Jan Oldřich Mannes. Dne 17. ledna 1714 obdržel za různé kusy pražského mramoru celkem 57 zl. 30 kr. Srov. Hauptstaatsarchiv Stuttgart, LandesschreibereiRechnungsbuch, Br. 197, fol. 399v, Účet za dodávku mramoru do Ludwigsburku, vystavený pražským kameníkem J. O. Mannesem.

${ }^{98}$ Fleischhauer, Barock im Herzogtum (pozn. 2), s. 149.

${ }^{99} \mathrm{Na}$ pískovcovém základu sochy Pallas Athény byly identifikovány čtyři barevné vrstvy: sádrový a křídový podklad, izolační olejová vrstva, barevný podklad (olejem vázaný oxid olovnato-olovičitý) a prášková mosaz v olejnaté vrstvě (Messingpulver in Ölhaltiger Schicht). Srov. Ulrich Schließl, Techniken der Faßmalerei in Barock und Rokoko. ... das alles von Bronce gemacht zu sein schiene, Stuttgart 1998, s. 61.

${ }^{100}$ Srov. nejnověji Merten (pozn. 7), s. 27. Na inspiraci soudobými vídeňskými vzory upozorňovala již starší literatura, srov. Blažíček, Sochařství baroku (pozn. 17), s. 119. 
mezi architekturou a sochou se promítá do celkového pojetí sochařské výzdoby. V obou vídeňských palácích se obři pod tíhou svých břemen prohýbají, sklánějí hlavy a bradami se dotýkají hrudníků, čímž vzniká dojem, že hlavní tíhu nesou na svých shrbených šíích. Ve srovnání s tím stojí Quitainerovi Atlanti téměř zpříma a ve vztahu k architektuře zaujímají pasivní postoj. Tento zjevný nedostatek iluzivního účinku byl v minulosti prŕíčinou jejich převážně negativního hodnocení v literatuře, aniž byl brán zřetel na to, že jejich dekorativní ladění může být záměrné a že vychází z celkového architektonického řešení schodiště, které se již z prostorových důvodů odchyluje od monumentální koncepce zmíněných vídeňských předobrazů. ${ }^{101}$

Přední dvojice Atlantů se k divákovi natáčí bokem. Obě sochy vycházejí z Quitainerovy oblíbené kompozice, založené na mírném kontrapostu a natočení horní poloviny těla včetně jedné ze svalnatých paží proti pohybu šíje a hlavy. Starší Atlant na pravé straně navazuje typikou tváře se zježeným knírem přes ústa na Quitainerovu sochu Herkula $v$ kůži nemejského lva. Měkce uhnětené svalstvo obou Atlantů, stejně jako jejich mohutné kyčle a masité hýždě odkazují k soše Meleagra z let 1709 až 1710. Stylizované detaily, jako je chomáč chlupů na hrudníku pravého obra, licousy jeho protějšku nebo prostorově působivý propletenec rukou nad hlavami obou Atlantů, oslabují Quitainerův obvyklý realismus a rozehrávají dekorativní složky jeho sochařského projevu.

U zadní dvojice Atlantů si vymezený prostor vynutil zpracování obou postav pro pohled zpředu. Typika jejich obličejů se liší jenom v nuancích, jako jsou zavřená či otevřená ústa. Atlanti se navzájem podobají také svou tělesnou stavbou a hlavami zapadlýma mezi rameny. Velký uzel na drapérii obra na pravé straně odkazuje k podobnému motivu na torzálně dochované soše Herkula s Kerberem z depozitáře zámeckého lapidária. Reliéfní pojetí do šiřky rozvinutých objemů působí archaicky a Atlanti díky němu odkazují až k modelačnímu řešení čtyř antických božstev ze střední části Leopoldovy kašny na Pražském hradě, jejíž sochařská výzdoba je dílem Jeronýma Kohla z roku $1686 .{ }^{102}$

Socha Pallas Athény stojí na podstavci s rozšířenou základnou v nice uprostřed zadní stěny schodiště a představuje úběžný bod celé jeho sochařské výzdoby. Bohyně je zobrazena nikoli jako přísná válečnice, hartusící zbrojí, ale jako svůdná mladá žena. Charakterizuje ji výrazné vyklenutí pravého boku, štíhlý pas, látka přimykající se na břiše mokře k tělu a ladný pohyb pravé ruky, kterou Athéna zvedá k čelence z pavích per na své hlavě. Pražský sochař touto prací opět navázal na senzualismus svých Bakchantek.

Podobnou slohovou notou se vyznačují již zmíněné dívčí bysty v oválných průhledech čelní stěny. Typikou usměvavých kulatých tváří a malých hlav na dlouhých šíjích rozvíjejí obě poprsí typiku použitou již u soch Caritas a Prudentiae. Téměř rokokovou svěžestí se vyznačují detaily, jako je nabíraný šat obou dívek, medailon s letopočtem zavěšený na řetězu kolem krku levé z nich nebo květy růží vpletené do vlasů jejího

101 Podle W. Fleischhauera jsou Atlanti „mehr muskulösen als kraftvollen“. D. Schulz ve své souhrnné studii z roku 2010 v souvislosti s výzdobou schodiště parafrázuje Fleischhauerův názor, jejž na české straně již dříve citoval V. Vančura. Pouze O. J. Blažíček zhodnotil Atlanty v pozitivnějším duchu a vyzdvihl jejich plynulé pohyby a drapérii, která je realistická a zároveň dekorativní. Srov. Fleischhauer, Barock im Herzogtum (pozn. 2), s. 149. Schulz (pozn. 41), s. 36-37. Blažíček, Sochařství baroku (pozn. 17), s. 118-119.

${ }^{102}$ K sochařské výzdobě kašny srov. Václav Vančura, Jeroným Kohl, Umění XXXIX, 1991, s. 519 (obr. 7), 521. 
protějšku. ${ }^{103}$ Obě bysty mají nepochybně své místo v ikonografické plánu sochařské výzdoby schodiště. Mohly by například ztělesňovat Múzy a spolu s Pallas Athénou tak opět glorifikovat vládnoucího vévodu jako milovníka krásných umění.

Výzdobou zámeckého křídla Riesenbau se v polovině roku 1714 Quitainerovo působení v Ludwigsburgu definitivně uzavřelo. V následující stavební sezóně se pro něho již práce nenašla, přestože o ni začátku roku 1715 z Prahy písemně žádal. ${ }^{104}$ Odmítavá odpověd’ württemberské stavební deputace na jeho dopis byla zdůvodněna malým rozsahem aktuálně prováděných sochařských prací. ${ }^{105}$ Mohla však souviset i s tím, že v prosinci 1714 při návratu ze studijní cesty do Paříže náhle zemřel architekt Nette, jenž si Quitainera ke spolupráci na výzdobě ludwigsburského zámku vybral a patrně se zasloužil o to, že zde mohl setrvat u díla plných pět let. ${ }^{106}$

\section{Několik poznámek na závěr}

Svým př́ijezdem do Ludwigsburgu v druhé polovině roku 1709 vstoupil Ondřej Filip Quitainer do kulturního prostředí, jehož parametry a nároky do značné míry určovala snaha co nejrychleji pozvednout württemberský dvůr na úroveň předních uměleckých center Evropy. Překotné úsilí o vyrovnání pocitovaného kulturního deficitu se projevovalo těkavým hledáním inspirace v sousedství (Rastatt) i ve vzdálenější cizině (Paříž, Berlín, Vídeň, Praha, Norimberk) a napomáhalo vzniku komunikačního pole, v němž se až eklekticky prolínaly různé umělecké směry a přístupy.

Quitainerovi se v Ludwigsburgu otevíraly široké možnosti uplatnění, a to již z hlediska rozsahu zakázek a jejich žánrového rozpětí, sahajícího od drobné řezby přes bukolickou zahradní plastiku až po monumentální díla spjatá s panovnickou reprezentací a inspirovaná slavnými antickými předlohami či Ripovou Ikonologií. Za současného stavu poznání lze jeho pětiletý tvưrčí pobyt spojit s dvanácti archivně doloženými a třinácti připsanými pracemi či soubory děl, což překračuje rozsah dosud známého œuvre, jež sochař během čtvrtstoletí vytvořil v rodných Čechách. Z hlediska poznání Quitainerova sochařského projevu má tedy zhodnocení jeho ludwigsburského díla zásadní význam.

Dosavadní bádání (Werner Fleischhauer) se soustředilo především na výčet sochařových prací na základě archivních zmínek a na lakonické komentáře k jejich výtvarné úrovni, anebo se, tak jako většina českých autorů, zaměřilo pouze na jeho poslední a zároveň nejznámější sochařskou realizaci, na Atlanty ze schodiště Riesenbau. Komplexní uměleckohistorické zhodnocení celého sochařova díla $\mathrm{v}$ Ludwigsburgu vedlo $\mathrm{k}$ několika překvapivým zjištěním. Quitainer se díky němu jeví jako sochař vyznačující se již v době

${ }^{103}$ Podle D. Schulze je na medailonu uvedeno datum dokončení stavby v roce 1714 . Srov. Schulz (pozn. 41), s. 37.

${ }^{104}$ Hauptstaatsarchiv Stuttgart, Rentkammerakten, Bü 2222, Protokoll Baudeputation vom 11. Februar 1715, Informace o dopisu O. F. Quitainera, dotazujícího se na pracovní možnosti v Ludwigsburgu v roce 1715 .

${ }^{105}$ Hauptstaatsarchiv Stuttgart, Rentkammerakten, Bü 2222, Protokoll Baudeputation vom 7. März 1715, Zpráva vedoucího stavebních prací o žádosti O. F. Quitainera.

${ }^{106}$ Podle W. Fleischhauera Nette pravděpodobně nelibě nesl Quitainerovo propuštění v záŕí 1712 a neochotně zadával zakázky jeho nástupci G. Ferrettimu. Srov. Fleischhauer, Barock im Herzogtum (pozn. 2), s. 150. 
svého příchodu v roce 1709 důvěrnou znalostí výtvarného odkazu antiky v jeho vrcholně barokní „redakci“, formované římským malírstvím a sochařstvím 17. století. Zároveň před námi vystupuje jako tvůrce, který byl přinejmenším zprostředkovaně v kontaktu s nejnovějšími podněty evropského sochařství své doby (Giulio Giuliani, snad Andreas Schlüter) a vnášel do výzdoby zámecké rezidence také impulsy soudobého pražského sochařství (Matěj Václav Jäckel, Jan Oldřich Mayer). Své výrazové prostředky přitom dokázal měnit a nuancovat $\mathrm{v}$ závislosti na funkčních vazbách díla, takže se u něho setkáváme jak s uměřeným antikizujícím pojetím soch balustrády čestného dvora, tak s hřejivou polohou alegorických postav Caritas a Prudentiae.

Některé formální nedostatky Quitainerových postav, týkající se zejména tělesných proporcí, dokládají, že mnohé z těchto inspiračních vlivů vstřebal nikoli systematickým studiem, ale spíše intuitivně, na základě grafických předloh či snad kratších poznávacích cest, na které jej podobně jako jeho předchůdce Zimmermanna mohl vyslat objednavatel. Přesto tvoři jeho dílo v Ludwigsburgu ze stylového hlediska relativně ucelený a vzájemně provázaný soubor, vyznačující se osobitou syntézou antikizujících kompozičních řešení, nadsazené vrcholně barokní modelace, malebně realistického pojetí detailů a psychologické podkresby typových tvárí.

Výzkum, jehož výsledky shrnuje tento příspěvek, vedl také ke zpřesnění a snad i rehabilitaci dosud rozkolísaného obrazu Ondřeje Filipa Quitainera v kontextu českého barokního sochařství ve zlomovém období uměleckého nástupu Ferdinanda Maxmiliána Brokoffa a Matyáše Bernarda Brauna. Zejména díky pozoruhodným mužským aktům Meleagra a Herkula s kưží nemejského lva se jako badatelské téma naskýtá opětovné prověření otázky Quitainerova údajného učitelského vztahu vůči Ferdinandu Maxmiliánovi Brokoffovi, popřípadě jeho staršímu bratrovi Michalu Janu Josefovi. K dalšímu studiu vybízí také problematika Quitainerových předloh a dále zasazení jeho sochařských prací do souvislostí freskové a štukové výzdoby vytvořené v Ludwigsburgu dalšími členy pražské umělecké družiny.

\section{SUMMARY}

\section{"Bildhauer in Stuttgart, sonsten aber aus Prag." Andreas Philipp Quitteiner as a member of the group of Prague artists in Ludwigsburg (1709 to 1714)}

This paper is focused on the Prague Baroque artist Andreas Philipp Quitteiner (16791729) in the context of his work at the chateau residence of the Württemberg dukes. In comparison with the other Prague-based participants in the Ludwigsburg artistic mission, Quitteiner has received the least attention of historians and art historians. While older literature (Werner Fleischhauer) was focused on an archivally based list of his works in Ludwigsburg, supplemented only with laconic comments, or selectively paid att ention to Quitteiner's most important works (Oldřich Jakub Blažíček), the aim of this study is to provide a concise understanding of the sculptor's work in Ludwigsburg against the background of contemporary Bohemian and European sculpture and older inspirational influences. 
In the introduction, the author raises doubts about the proposition formulated by Oldřich Jakub Blažíček that the thirty-year-old Quitteiner departed to Württemberg in 1709 as an inexperienced sculptor and only step by step worked his way up alongside his respected Prague fellows - plasterers Donato Giuseppe Frisoni and Tommaso Soldati and under the surveillance of architect Johann Friedrich Nette. Quitteiner's artistically mature works from the beginning of his stint in Ludwigsburg (particularly Meleagros from 1709-1710) do not correspond to this opinion. Furthermore, archival sources give evidence of Nette's uncompromising demands on his collaborators, which became the cause of his rift with the court sculptor Zimmermann not long before the arrival of the Prague master. With respect to these findings, the research on Quitteiner's Prague beginnings, which were probably connected with the circle of architect Giovanni Battista Alliprandi, appears to be more important.

In other parts of the paper, the author focuses in detail on the periods of the sculptor's work in Ludwigsburg, starting with the decoration of a generously designed Frenchstyle garden, through allegorical sculptures in the vestibule of the Ordensbau wing, Atlantes and busts in the opposite wing called Riesenbau and six gilded figurative sculptures on the courtyard balustrade to various small carving and stone sculpture works. The author underlines that unusually wide range of opportunities opened to Quitteiner in terms of the scope of genres as well as the quantity of completed commissions. His works in Ludwigsburg are consequently of fundamental importance for recognition of his artistic temperament.

It has been demonstrated that at the time of his arrival, Quitteiner already exhibited surprisingly intimate knowledge of the ancient canon in the robust interpretation of Roman painting and sculpture from the first half of the 17th century. His Ludwigsburg works from later periods were characterised not only by vivid experience with contemporary Prague sculpture (Matthäus Wenzel Jäckel, Johann Ulrich Mayer), but also an at least indirect familiarity with the best works of European sculpture of the time (Giovanni Giuliani and, presumably, Andreas Schlüter). Quitteiner was able to alternate and combine these formal approaches and means of expression - albeit in a simplified form - without slipping into epigonism. Despite qualitative fluctuation in output of his workshop and a certain inclination toward ponderousness, his sculptural style was clearly profiled and characterised by a synthesis of classical compositional solutions, High Baroque modelling, lyrical stylisation of realistically felt details and psychological outlines of typical yet expressive faces of a pseudo-portraiture character.

This more accurate perception of the sculptor's artistic profile contributed even to the rehabilitation of Quitteiner's image in the context of Prague sculpture at the beginning of the 18th century. Among other things, a new research perspective opens regarding the traditional (yet rejected by the more recent literature) story that Quitteiner took part in the artistic training of one of the greats of the Central European Baroque sculpture Ferdinand Maxmilan Brokoff. 


\section{POUŽITÉ ARCHIVNÍ PRAMENY}

Hauptstaatsarchiv Stuttgart, Bü 2264, Dopis dvorního sochaře Sebastiana Zimmermanna vévodovi Eberhardu Ludwigovi z 5. srpna 1708.

Hauptstaatsarchiv Stuttgart, Rentkammer-Rechnungsbuch, Bü 970, 1709-10, fol. 156, Potvrzení o platbách O. F. Quitainerovi za sochy Diany, Meleagera a za třetí nejmenovanou sochu (1709-1710).

Hauptstaatsarchiv Stuttgart, Landesschreiberei-Rechnungsbuch Bd. 194, fol. 413, Potvrzení o platbě O. F. Quitainerovi za čtyři stolky (,tableaux“) ze dne 27. 7. 1710.

Hauptstaatsarchiv Stuttgart, Landesschreiberei-Rechnungsbuch Bd. 194, fol. 413, Potvrzení o platbě O. F. Quitainerovi za hrací stolek a rámy (?).

Hauptstaatsarchiv Stuttgart, Kirchenrat, verschlossene Registratur, Bü 813, nečíslováno (po čísle 26), Smlouva mezi J. F. Nettem a O. F. Quitainerem, týkající se dvou dubových vstupních dveří.

Hauptstaatsarchiv Stuttgart, Rentkammerakten, Bü 2222, Protokoll Baudeputation 3. Juni 1712, Informace o preposlání smlouvys O. F. Quitainerem (sochařské práce ve Fürstenbau za 900 zl.).

Hauptstaatsarchiv Stuttgart, Rentkammerakten, Bü 2222, Protokoll Baudeputation vom 4. Juli 1712, Informace o cenovém odhadu týkajícím se soch Caritas a Prudentiae (Liebe und Vorsichtigkeit).

Hauptstaatsarchiv Stuttgart, Rentkammerakten, Bü 2222, Protokoll Baudeputation vom 10. September 1712, Dekret o propuštění O. F. Quitainera ze služeb.

Huptstaatsarchiv Stuttgart, Rentkammerakten, Bü 2222, Protokoll Baudeputation vom 12. September 1712, Účet sochaře Ferrettiho.

Hauptstaatsarchiv Stuttgart, Rentkammerakten, Bü 2222, Protokoll Baudeputation vom 14. November 1712, Ǔčet O. F. Quitainera za vyřezávané dveře.

Hauptstaatsarchiv Stuttgart, Geheimer Rat, Bü 3032, Nr. 83, Dopis vrchního maršálka G. F. Forstnera vévodovi Eberhardu Ludwigovi.

Hauptstaatsarchiv Stuttgart, Rentkammerakten, Bü 2222, Protokoll Baudeputation vom 17. Juli 1713, Účet O. F. Quitainera za řezbářské práce (Spiegelrahm).

Hauptstaatsarchiv Stuttgart, Landesschreiberei-Rechnungsbuch, Br. 197, fol. 399v, Účet za dodávku mramoru do Ludwigsburku, vystavený pražským kameníkem J. O. Mannesem.

Hauptstaatsarchiv Stuttgart, Rentkammerakten, Bü 2222, Protokoll Baudeputation vom 25. Mai 1714, Výčet sochařských prací, realizovaných O. F. Quitainerem v „Riesenbau“.

Hauptstaatsarchiv Stuttgart, Geistliche Ämterrechnungen, Bü 8736, Jahresausgaben 1714-1715, fol. 172, Učet O. F. Quitainera za sochařské práce v „Riesenbau“.

Hauptstaatsarchiv Stuttgart, Rentkammerakten, Bü 2222, Protokoll Baudeputation vom 11. Februar 1715, Informace o dopisu O. F. Quitainera, dotazujícího se na pracovní možnosti v Ludwigsburgu v roce 1715.

Hauptstaatsarchiv Stuttgart, Rentkammerakten, Bü 2222, Protokoll Baudeputation vom 7. März 1715, Zpráva vedoucího stavebních prací o žádosti O. F. Quitainera.

\section{VÝBĚROVÁ BIBLIOGRAFIE}

Oldřich J. Blažíček, Sochařství baroku v Čechách, Praha 1958.

Gottfried Johann Dlabacž, Böhmische Künstler, Hesperus. Ein Nationalblatt für gebildete Leser 82, Dezember 1813, col. 650-651.

Gottfried Johann Dlabač̌, Allgemeines historisches Künstlerlexikon für Böhmen und zum Theil auch für Mähren und Schlesien, Band I-III, Prag 1815.

Werner Fleischhauer, Schlossmuseum Ludwigsburg, amtlicher Führer, Stuttgart 1958

Werner Fleischhauer, Barock im Herzogtum Württemberg, Stuttgart 1958.

Jan Holeček, Jakub Auguston, in: Petr Macek - Richard Biegel - Jakub Bachtík (eds), Barokní architektura v Čechách, Praha 2015, s. 376-387.

Corinna Höper - Andreas Henning, Das Glück Würtemberks, Zeichnungen und Druckgraphik europäischer Künstler des 18. Jahrhunderts, Stuttgart 2004.

Martin Hořák, Dvě generace pražských barokních sochařu. Ondřej Filip a Jan Antonín Quitainerovi, in: Staletá Praha XXVIII, 1/2012, s. 2-30. 
Martin Hořák, Barokni sochařská dílna Ondřeje Filipa a Jana Antonína Quitainerových, (disertační práce), Ústav pro dějiny uměni FF UK, Praha 2019.

Jiří Kaše, Projekt restaurátorské akce. Sochařská výzdoba palácové atiky, č.p. 347/III Vlašská 19, Lobkovický (Přehořovský) palác, Praha 1985.

Fritz-Eugen Keller, Die Schlusssteine der Bogen am Erdgeschoss des Zeughauses, in: Hans-Ulrich Kessler (ed.), Andreas Schlüter und das barocke Berlin, Berlin 2014, s. 136-167.

Martin Krummholz, Giovanni Battista Alliprandi, in: Petr Macek - Richard Biegel - Jakub Bachtík (eds), Barokní architektura v Čechách, Praha 2015, 181-187, s. 236-248.

Dobroslav Líbal (ed.), Stavebně historický průzkum, Palác Přehořovských z Kvasejovic. Malá Strana č.p. 347/III, Praha 1968.

Martin Mádl, Umělecká výměna mezi Prahou a Ludwigsburgem, Akademický bulletin Akademie věd České republiky, 2009, č. 111, s. 24-25.

Publius Ovidius Naso, Proměny, Praha 1969.

František Martin Pelzel, Abbildungen böhmischer und mährischer Gelehrten und Künstler II., Prag 1775.

Antonín Podlaha, Materiálie k slovníku umělců a uměleckých řemeslníkủ v Čechách, Památky archeologické XXVII, 1915, s. 160-188.

Emanuel Poche - Pavel Preiss, Pražské paláce, Praha 1977.

Cesare Ripa, Iconologia per Cesare Ripa Perugino, cavallier di SS Mauritio et Lazaro. Divisa in tre libri. Ampliata dal. sig. cav. Gio. Zaratino, castellini Romano, Venetia 1645.

Cesare Ripa, Ikonologie, Praha 2019.

Hans-Joachim Scholderer - Kirsten Keidl - Birgit Klee, Ludwigsburg 2004, Altes Corps de Logis, Barockgalerie, Fassaden und Dächer, Garten, Ludwigsburg 2004.

Ulrich Schließl, Techniken der Faßmalerei in Barock und Rokoko. ...das alles von Bronce gemacht zu sein schiene, Stuttgart 1998.

Ulrike Seeger, Vienna, Prague, Paris and Augsburg: The Provisioning of Interior Decoration in the Ludwigsburg Residence, in: Spephan Hoppe - Krista Breitling - Stefan De Jonge (eds), The Interior as an Embodiment of Power, Heidelberg 2018, s. 193-204.

Daniel Schulz, Mars, Venus, Bacchus \& Co.: Die barocken Groß-Skulpturen des Ludwigsburger Schlosses, Ludwigsburger Geschichtsblätter 64/2010, s. 23-59.

Staatliche Schlösser und Gärten Baden-Württemberg (Hrsg.), Schloss Ludwigsburg. Geschichte einer barocken Residenz. Silberburg, Tübingen 2004.

Jana Tischerová, Matěj Václav Jäckel. Sochař českého baroka 1655-1738, Praha 2013.

Robert Uhland, Eberhard Ludwig, Herzog von Württemberg, in: Neue Deutsche Biographie (NDB), Band 4, Berlin 1959, s. 237-238.

Václav Vančura, Př́spěvek k dílu Quitainerů, Umění XXXVII, 1989, s. 128-153.

Václav Vančura, Jeroným Kohl, Umění XXXIX, 1991, s. 512-532.

Publius Vergilius Maro, Aeneis, Praha 1933.

Julia Kloss-Weber, Die Villa Kameke, in: Hans-Ulrich Kessler (ed.), Andreas Schlüter und das barocke Berlin, Berlin 2014, s. 416-435.

Karl Weiß, Schloß Ludwigsburg. Baugeschichtliche Abhandlung über die von Johann Friedrich Nette erbauten Teile. Ein Beitrag zur Kunstgeschichte des 18. Jahrhunderts, Stuttgart (Dissertation, Technische Hochschule Stuttgart), Stuttgart 1914.

Rudolf Wittkower, Gian Lorenzo Bernini, 3rd. edition, Ithaca-New York 1981.

Rudolf Wittkower, Art and Architecture in Italy: 1600-1750, 3rd. revised edition, Harmondsworth-Baltimore - Ringwood 1973. 

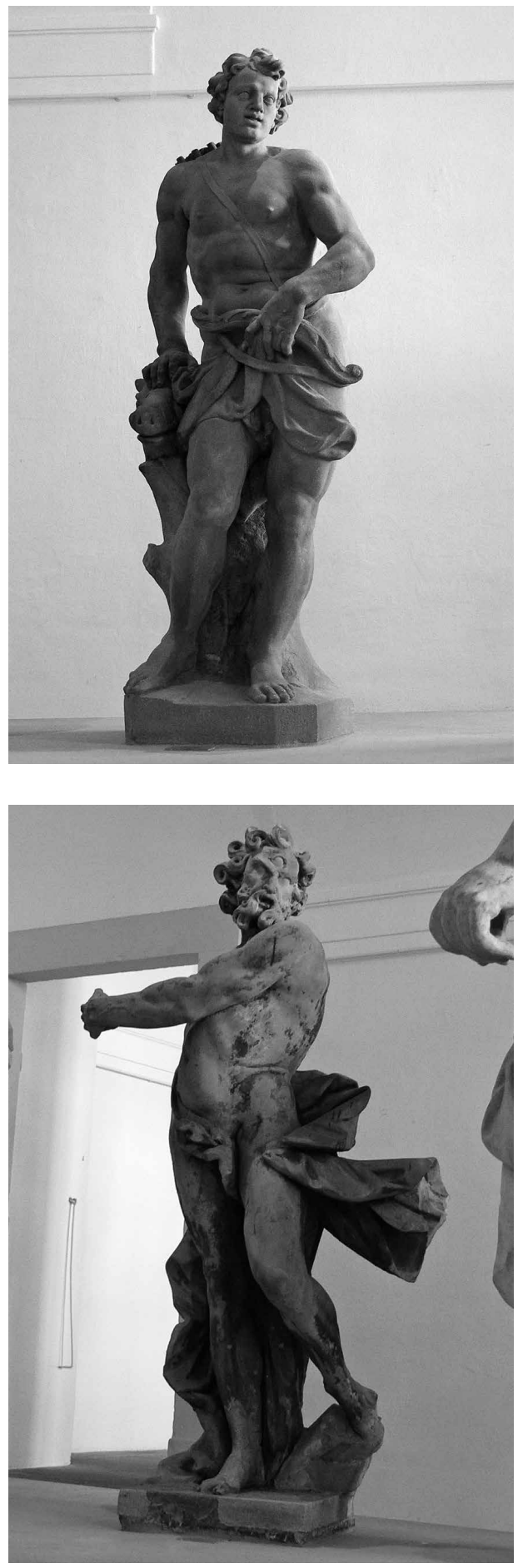

Obrázek 1. Ondřej Filip Quitainer, Meleagros, 1709-1710, pískovec, nadživotní velikost. Zámek Ludwigsburg, lapidárium. Snímek Martin Hořák

Obrázek 2. Ondřej Filip Quitainer, Polyfémos, po 1710 , pískovec, nadživotní velikost. Zámek Ludwigsburg, lapidárium. Snímek Martin Hořák 

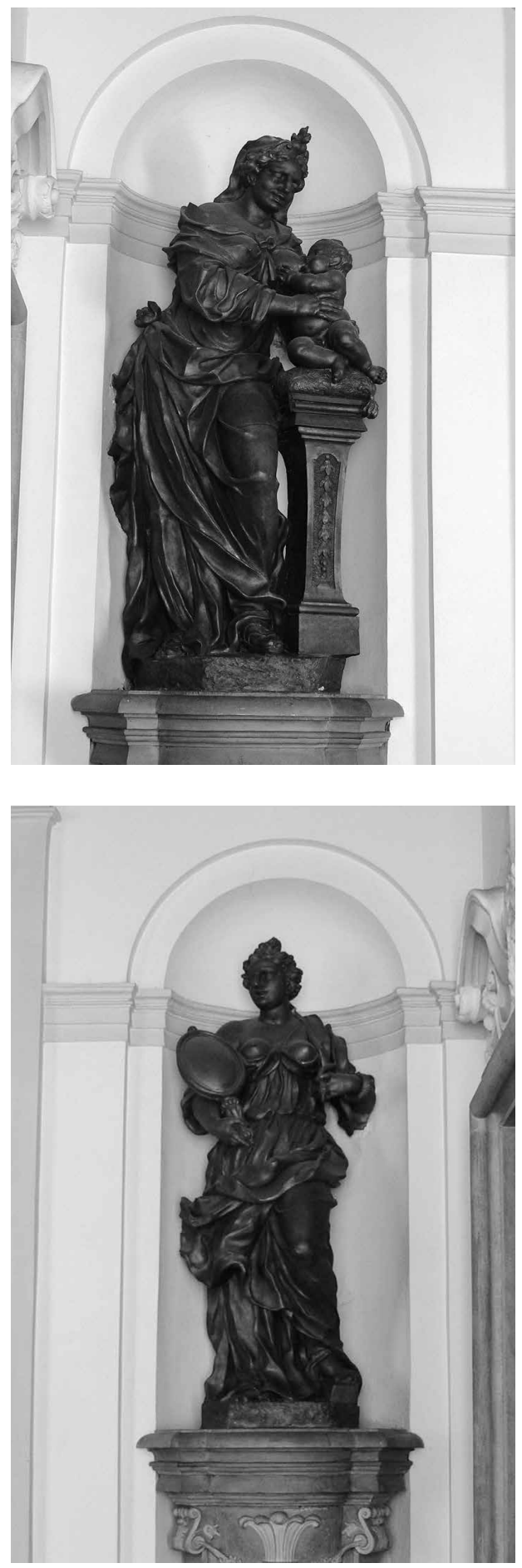

Obrázek 3. Ondřej Filip Quitainer, Catitas, 1712, pískovec, původní polychromie, nadživotní velikost. Zámek Ludwigsburg, Ordensbau. Snímek Martin Hořák

Obrázek 4. Ondřej Filip Quitainer, Prudentia, 1712, pískovec, původní polychromie, nadživotní velikost. Zámek Ludwigsburg, Ordensbau. Snímek Martin Hořák 

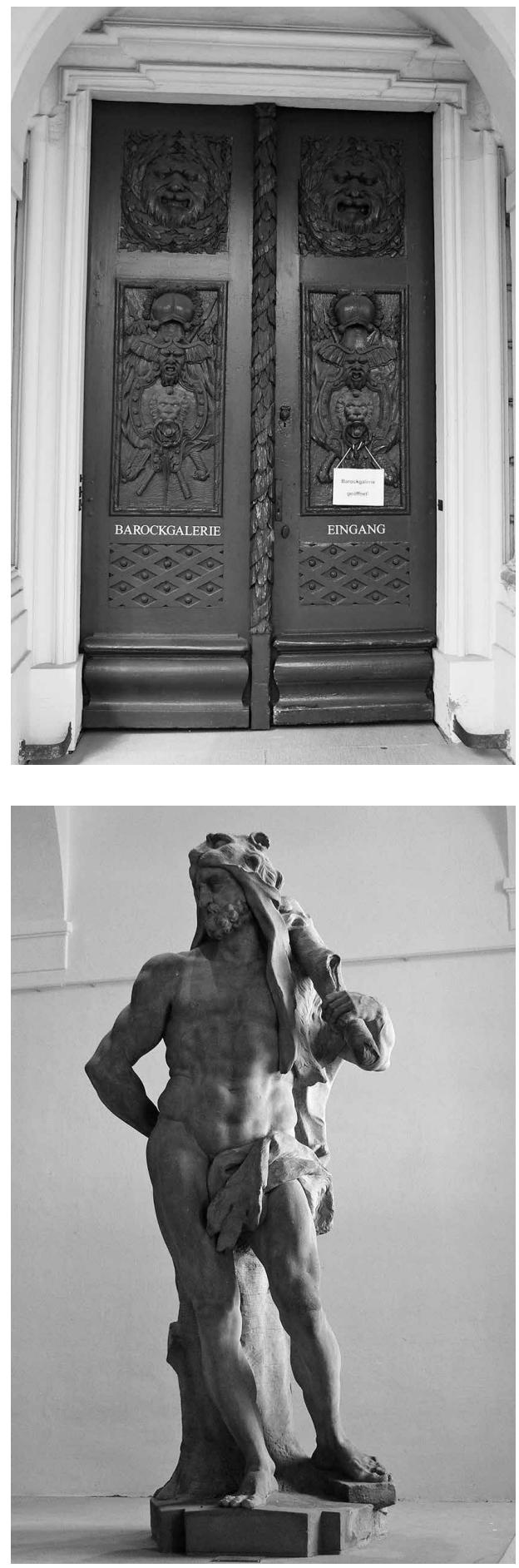

Obrázek 5. Ondřej Filip Quitainer, řezbářská výzdoba vstupních dveř́i Fürstenbau, 1711, dubové dřevo, původně zlaceno. Zámek Ludwigsburg, lapidárium. Snímek Martin Hořák

Obrázek 6. Ondřej Filip Quitainer, Herkules $v$ kůži nemejského lva, 1713, pískovec, nadživotní velikost. Zámek Ludwigsburg, lapidárium. Snímek Martin Hořák 

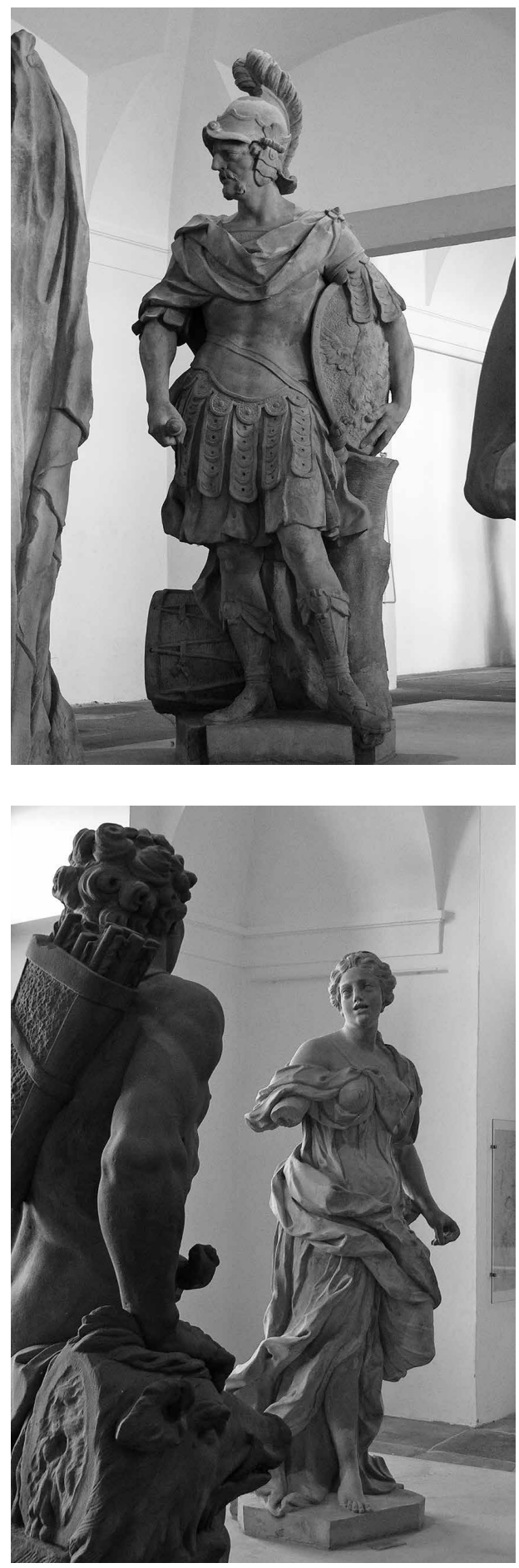

Obrázek 7. Ondřej Filip Quitainer, Mars, 1713, pískovec, nadživotní velikost. Zámek Ludwigsburg, lapidárium. Snímek Martin Hořák
Obrázek 8. Ondřej Filip Quitainer, Atalanta (?), 1713, pískovec, nadživotní velikost. Zámek Ludwigsburg, lapidárium. Snímek Martin Hořák 


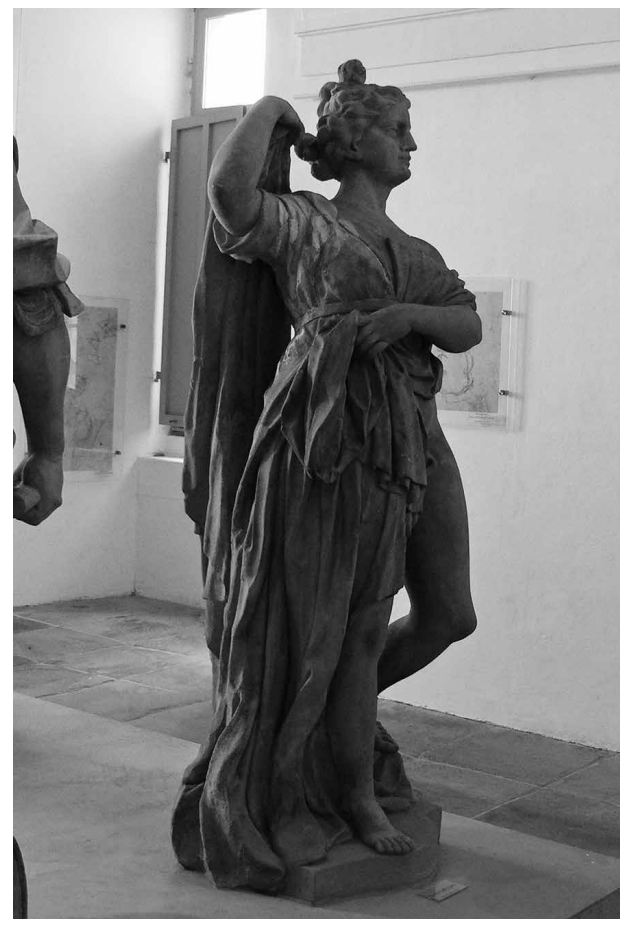

Obrázek 9. Ondřej Filip Quitainer, Venuše Kallipygos, 1713, pískovec, nadživotní velikost. Zámek Ludwigsburg, lapidárium. Snímek Martin Hořák

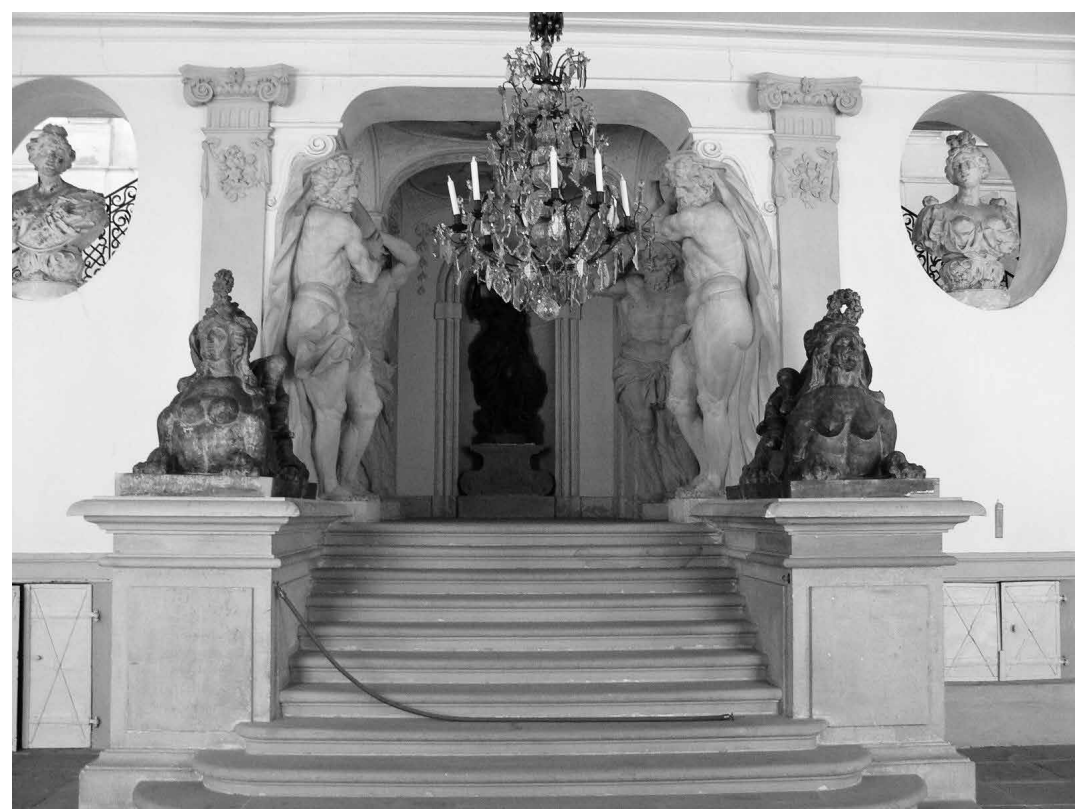

Obrázek 10. Ondřej Filip Quitainer (čtyři Atlanti, Pallas Athéna, dvě bysty) a Sebastian Zimmermann (sfingy s putti), výzdoba slavnostního schodiště, 1714, pískovec. Zámek Ludwigsburg, Riesenbau. Snímek Martin Hořák 